\title{
Long-term human impact and environmental change in mid-western Ireland, with particular reference to Céide Fields - an overview
}

\author{
Michael O'Connell, Karen Molloy, and Eneda Jennings \\ Palaeoenvironmental Research Unit, School of Geography, Archaeology and Irish Studies, \\ National University of Ireland Galway, Galway, Ireland
}

Correspondence: Michael O’Connell (michael.oconnell@nuigalway.ie)

Relevant dates: $\quad$ Received: 10 August 2019 - Revised: 25 October 2019 - Accepted: 3 December 2019 Published: 11 February 2020

How to cite:

O'Connell, M., Molloy, K., and Jennings, E.: Long-term human impact and environmental change in mid-western Ireland, with particular reference to Céide Fields - an overview, E\&G Quaternary Sci. J., 69, 1-32, https://doi.org/10.5194/egqsj-69-1-2020, 2020.

Abstract:

This paper presents new palaeoecological data from north County Mayo (Co. Mayo), western Ireland, and reviews published data with a view to achieving a better understanding of the timing and nature of early farming in the region, its impact on the natural environment, and the factors, including climate change, that influenced mid- and late-Holocene vegetation dynamics and farming in the region. A long pollen profile from Glenulra, a deep basin situated within Céide Fields, and short profiles from blanket peat that overlies the prehistoric stone-wall field system provide unambiguous evidence for substantial farming, including widespread woodland clearance, in the early British and Irish Neolithic (beginning ca. $3800 \mathrm{BCE}$ ). This was followed by a distinct lull that lasted several centuries until farming activity resumed again, at first modestly (at ca. $2700 \mathrm{BCE}$ ) and then more markedly from $2350 \mathrm{BCE}$, i.e. at the Neolithic-Chalcolithic transition. It is argued on the basis of this and other palaeoecological evidence, including pollen analytical investigations at nearby Garrynagran, that, contrary to recent suggestions, there is no reason to doubt the widely held view that the stone-wall field system - unique in a western European Neolithic context - is correctly ascribable to the earlier part of the British and Irish Neolithic. The history of pine growing in bog contexts (mainly blanket bog) in the region is considered in the light of ${ }^{14} \mathrm{C}$ dates derived from pine timbers, and the results of dendrochronological investigations at Garrynagran that have enabled two floating pine chronologies to be constructed, are presented. The climatic implications of these data are discussed within local and wider regional contexts.

Kurzfassung: Diese Studie präsentiert neue paläoökologische Daten aus dem nördlichen Co. Mayo (Grafschaft Mayo), Westirland, und überprüft bereits veröffentlichte Daten in Hinblick auf ein besseres Verständnis der Zeitstellung und des Typus früher Landwirtschaft in der Region, deren Auswirkungen auf die natürliche Umwelt, und auf Faktoren, einschließlich des Klimawandels, die die mittelbis spätholozäne Vegetationsdynamik und Landwirtschaft der Region beeinflusst haben. Ein langes Pollenprofil aus Glenulra, einem tiefen Becken im Bereich der Céide Fields, und kurze Profile aus Torfen, die das prähistorische System aus Steinmauern flächenhaft überlagern, liefern eindeutige 
Beweise für umfangreiche Landwirtschaft, einschließlich ausgedehnter Rodung von Waldgebieten, im frühen Britischen und Irischen Neolithikum (beginnend ca. 3800 BC). Daran schloss eine ausgeprägte Flaute der landwirtschaftlichen Nutzung an, die mehrere Jahrhunderte anhielt. Die landwirtschaftliche Nutzung fing wieder an zuzunehmen, zuerst mäßig um ca. 2700 BC und viel stärker um ca. 2350 BC zur Zeit des Neolithisch-Chalkolithischen Übergangs. Auf der Grundlage dieser und anderer paläoökologischer Belege, einschließlich pollenanalytischer Untersuchungen im nahe gelegenen Garrynagran, wird argumentiert, dass es im Gegensatz zu jüngsten Vorschlägen keinen Grund gibt, die weit verbreitete Ansicht zu bezweifeln, dass das System von durch Steinmauern umschlossenen Feldern - in Europa in neolithischen Kontext einzigartig - korrekterweise dem früheren Teil des Britisch-Irischen Neolithikums zugeschrieben wird. Auf der Grundlage von vorliegenden ${ }^{14} \mathrm{C}$ Daten, die an Kiefernhölzern gewonnen wurden und basierend auf den Ergebnissen dendrochronologischer Untersuchungen in Garrynagran, die die Erstellung zweier hängender Kiefern-Chronologien ermöglichten, wird die Geschichte des Anbaus von Kiefern im Kontext von Mooren (hauptsächlich geländebedeckende Moore) vorgestellt. Die klimatischen Implikationen dieser Daten werden im lokalen und weiteren regionalen Kontext diskutiert.

\section{Introduction}

The importance of north Mayo, western Ireland (Fig. 1), for understanding various aspects of early human impact on the environment and especially farming impact during the $\mathrm{Ne}$ olithic and Bronze Age in western Ireland, and indeed in Atlantic Europe generally, has long been recognised. Surveys and excavations of megalithic tombs in the 1960s served to highlight the already-known dense concentration of court and wedge tombs in the north Mayo region (de Valéra, 1965; de Valéra and Ó Nualláin, 1964). This was followed by archaeological investigations that were initially centred on prebog field systems in the coastal Behy and Glenulra townlands (referred to as Céide Fields) and Belderrig, $6 \mathrm{~km}$ to the west (Fig. 1).

The uniqueness of the field system arises from the regularity with which it is laid out, its extensiveness, the early date of its construction and use in prehistory, and its excellent preservation due to the growth of blanket-bog peat that had already commenced on a wide scale by the mid-Holocene. Since its significance as evidence for land enclosure was first fully appreciated by Irish archaeologists in the late 1960s, it has been widely regarded as pertaining to the Neolithic (see below). In Ireland and especially in Britain, comparably sophisticated systems invariably date to the Bronze Age or Iron Age (Fowler, 1983; Overland and O'Connell, 2008; O'Brien, 2009). It appears to be mainly because of a lack of suitable comparanda in Britain and Ireland that Whitefield (2017) argued for a Bronze Age date for Céide Fields and furthermore suggested that a late Bronze Age or Iron Age date should not be ruled out. Interestingly, within a central European context (the loess region), Bakels (2009, p. 32), with reference to Neolithic field systems in that extensive region, states that "no traces of them [fields] are left after millennia of farming the same plots". In other words, use of the land by succeeding cultures has destroyed the evidence for Neolithic fields if such evidence did exist in the first instance. This general background serves to emphasise the uniqueness of the Céide Fields and also shows the importance of establishing beyond all reasonable doubt - this is the purpose of this paper - the chronology and environmental conditions associated with the establishment, use and ultimately abandonment of the field system and growth of blanket bog.

It is important too not to confuse Céide Fields with "Celtic fields", a term used to refer to Bronze Age and Iron Age arable field systems known mainly from northern Continental Europe (Behre, 2000; Arnoldussen and van der Linden, 2017) and also Britain (Fowler, 1983). "Céide" in Irish indicates a flat-topped hill (https://www.logainm.ie/ga/, last access: 1 November 2019) which aptly describes the elevated ground on which the central part of the field system lies (Fig. 1b; also Fig. S8a in the Supplement).

The first publications by the main excavator, Seamas Caulfield, consisted of excavation reports (Caulfield, 1972, $1973,1974,1975,1976)$ that were followed by two substantial papers (Caulfield, 1978, 1983) and various minor but useful publications mainly in the form of field guides by the excavator (Caulfield, 1980, 1988, 1992). More recent publications by Caulfield $(2013,2014,2018)$ provide interesting overviews in which various ideas regarding the environmental contexts of prehistoric farming in north Mayo are proffered. The 2018 publication consists of a chapter in an attractive and informative book (the most substantial available to date) that was published (in English and Italian editions) to mark the award of the International Carlo Scarpa Prize for Gardens 2018 to the Céide Fields project (Boschiero et al., 2018). In further chapters various archaeological, geographical and cultural aspects of the north Mayo region are explored. Warren (2018), for instance, provides an overview of the archaeology of north Mayo, including dating evidence, with particular reference to his excavations of a late Mesolithic site at Belderg More, close to the Belder- 

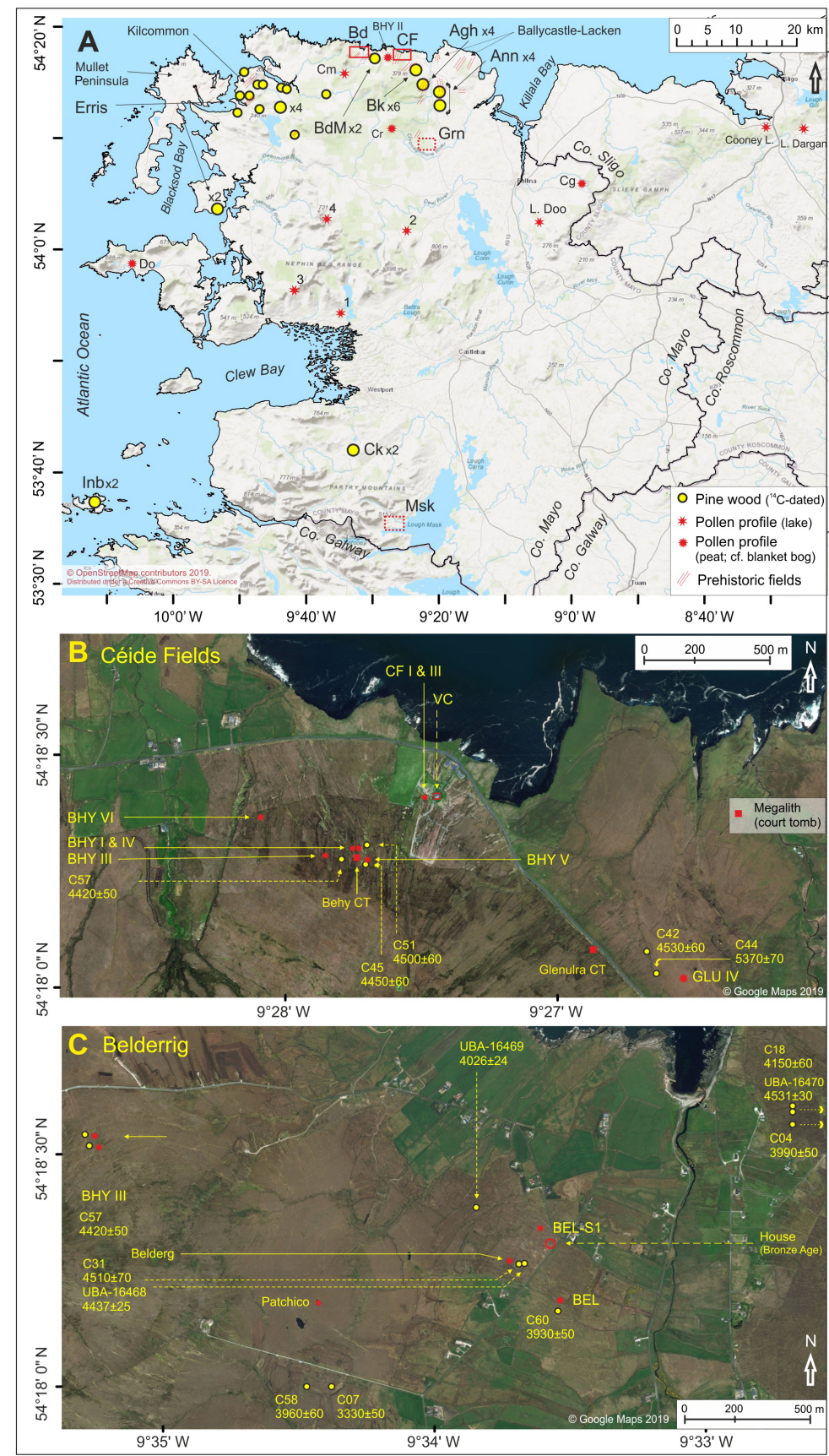

Figure 1. Maps relating to the study areas. (a) Overview map of Co. Mayo and parts of the adjoining counties. Rectangles indicate areas for which detailed maps are provided, i.e. Belderrig (Bd) and Céide Fields (CF) (solid red outlines; see Fig. 1b, c) and Garrynagran (Grn) and Shanvallycahill, Lough Mask (Msk) (dashed red outlines; see Fig. 2). Dashed red parallel lines indicate presence of prehistoric field boundaries (after Caulfield et al., 2011a). Locations of ${ }^{14} \mathrm{C}$-dated pine timbers (individual specimens and several specimens; nos. are indicated) and pollen profiles are shown. (b) Megaliths (court tombs) referred to in the text and locations of pollen profiles and ${ }^{14} \mathrm{C}$-dated pine timbers in the Céide Fields area. (c) Results of ${ }^{14} \mathrm{C}$ redating of pine timbers and other details relating to the Belderrig area (UBA-16470 is from pine on a wall in Belderg More; this and dates C04 and C18 lie $130 \mathrm{~m}$ to the east of the image margin). UBA dates, rather than the original UCD ${ }^{14} \mathrm{C}$ dates for the redated samples, are indicated. Abbreviations, in addition to those given above, are as follows: (CT) court tomb; (VC) visitor centre; $(\mathrm{Ck})$ Carrowkennedy; $(\mathrm{Cg})$ Carrownaglogh; $(\mathrm{Cm})$ Cregganmore; $(\mathrm{Cr})$ Croaghaun East; (Do) Dooega, Achill; and (Inb) Cloonamore, Inishbofin. The provenance of pine stumps in north Mayo is indicated as follows (Fig. 1a): (Agh) Aghoo; (Ann) Annagh More and Annagh Beg; (Bk) Ballyknock; and (BdM) Belderg More. The widely scattered specimens from north-western Mayo are referred to by the regional name Erris rather than by the respective townland names. Numbered pollen profiles from lakes are as follows: (1) L. Aisling; (2) L. Clevala; (3) L. Anaffrin; and (4) L. Corslieve. For further details see Sect. 1. Sources of the base maps are as follows: (Fig. 1a) OpenStreetMap contributors and the GIS user community (COpenStreetMap contributors 2019; distributed under a Creative Commons BY-SA License), accessed 20 May 2019, and (Fig. 1b, c) @Google Maps, accessed 21 May 2019. 
rig pre-bog, stone-wall field system, while Byrne (2018) describes and discusses in considerable detail the field systems and megalithic tombs of the Ballycastle-Lacken region, i.e. the largely blanket-bog-covered area that lies between Bunatrahir Bay and Killala Bay (Fig. 1a).

Syntheses of the large body of information relating to the Céide Fields and the north Mayo region generally, prepared with support from the Irish National Strategic Archaeological Research (INSTAR) Programme, are available in Caulfield et al. (2011a, b), but a final synthesis of the archaeological investigations in the region has yet to be published. The chronology of the field systems, employing Bayesian methodologies, is reviewed in Cooney et al. (2011), and, more recently, Whitefield (2017) has argued that, contrary to the generally accepted view, the field systems in north Mayo, including those at Céide Fields and Belderrig, relate to the Bronze Age and most likely the late Bronze Age rather than the Neolithic.

At Belderrig (includes Belderg Beg, Belderg More and Geevraun townlands), where pre-bog stone walls were first recorded, archaeological excavation that involved removal of cutover blanket-bog peat revealed the remains of a substantial roundhouse and also well-defined, extensive cultivation ridges that overlay, at least in part, a mineral soil with ard marks (Figs. 1c and S8b). Radiocarbon dating indicated that the house related to the late Bronze Age (structural timber from the house gave the ${ }^{14} \mathrm{C}$ date $3170 \pm 85 \mathrm{BP}$; Caulfield, 1978), while the cultivation ridges (and also the ard marks) beside the house were regarded as mainly predating the house but also continuing after house construction (Caulfield, 1975). Initially, it was considered that the ard marks might relate to the Neolithic, but it is now accepted that, like the cultivation ridges, these relate to the late Bronze Age (Caulfield, 2018; Verrill and Tipping, 2010a). The results of recent ${ }^{14} \mathrm{C}$ dating suggest considerable activity at the house site extending over a prolonged period in the middle to late Bronze Age (Caulfield et al., 2011a).

The field system at Céide Fields has been shown to be considerably more extensive than initially realised. Archaeological surveys, mainly involving probing to determine the location of stone walls hidden by blanket-bog cover, have demonstrated that the stone-wall system extends over an area exceeding 1000 ha, though not always with the same highly regular pattern as initially described for Céide Hill, i.e. the spur of sloping ground that extends from Maumakeogh ( $328 \mathrm{~m}$ a.s.1.) to the cliffs immediately to the north of the Céide Fields Visitor Centre (Caulfield, 2018). At Céide Fields stone walls constructed on peat have not been reported, which contrasts with the situation in Castletown on the eastern side of Bunatrahir Bay (see Ballycastle-Lacken, Fig. 1a) where Byrne (2018) reports a series of pre-bog stone walls on mineral soils and also stone walls resting on a thin layer of peat. At Belderrig, where the stone walls also rest on mineral soil, a section of wall was extended onto a thin peat layer (the maximum thickness of peat beneath the wall is $\sim 60 \mathrm{~cm}$; oak stakes were used to continue the line of the wall onto deeper peat) in the mid-Bronze Age (ca. 1450 BCE based on two ${ }^{14} \mathrm{C}$ dates for the oak stakes; Caulfield, 1973).

Extensive stone-wall field systems, again in association with megalithic tombs, have been discovered and surveyed in Rathlackan and adjoining areas to the east (Byrne, 2018; Ballycastle-Lacken in Fig. 1a) and Kilcommon to the west (Dunne, 1985). Pre-bog stone walls have also been recorded elsewhere in the region including on the Mullet Peninsula (Warren, 2018) and at Blanemore beside Garrynagran (Figs. 1a and S8c).

In this paper, the focus is on palaeoecological investigations that have been carried out at various times by the authors and other scientists. The overall aim of these investigations was to establish and secure the chronology of the field systems, reconstruct the type of farming that was pursued and assess its impact on local environments, and establish the timing and causes of the extensive blanket bog that defines the region as a whole (Praeger, 1947). The present review is timely given recent controversies and especially the uncertainties arising from the questioning of the age of the field systems (Whitefield, 2017). It is also an opportune time to present and critically discuss the considerable body of palaeoenvironmental information now available and to relate this to the archaeological data gained through survey and excavation. Of particular interest is the dating of basal peats, which serves as an indicator of the beginning of blanket-bog formation, and also the history of pine (Pinus sylvestris) in the region, the fossil timbers of which are frequently encountered at the base of, and within, blanket-bog peat (Fig. S8b). The term "pine flush" is used here to designate pine trees (usually several rather than isolated specimens) that grew on peat, evidence for which is widely to be seen on cutover bog as stumps of various sizes and occasionally as tree trunks. Oak timbers are also present but these are much less frequent. A pine flush is usually readily identifiable in pollen profiles (already noted by Jessen, 1949; see also O'Connell and McDonnell, 2019) as elevated Pinus pollen values. The term may conjure up a single event or phase at a particular site, but this is not necessarily always the case. Indeed, it was an objective of the present investigations to gain a better understanding of the nature and chronology of pine flushes in a north-west Mayo context. The pine flush phenomenon is also potentially an important chronological marker in that it provides a reliable terminus ante quem for wall construction where walls rest on mineral ground, which is usually the case (see above). Specimens (stumps and/or tree trunks) that are on mineral soil also provide good chronological markers since it can be assumed that peat growth commenced within a few decades of death (otherwise it is unlikely that the timbers would have been preserved). 
2 Overview of completed palaeoecological investigations with particular reference to north Mayo

In this section, an overview is given of the palaeoecological investigations, both published and unpublished, that the authors are aware of and that have a bearing on Holocene environmental change in north Mayo, particularly as regards farming and human impact. Geographical and other details of the sites are summarised in Table S1a.

\subsection{Earliest palaeoecological investigations (1970s)}

\subsubsection{Investigations at Céide Fields (Behy court tomb) by Smith et al. (1973)}

In the early 1970s, investigations that included pollen analysis and ${ }^{14} \mathrm{C}$ dating were carried out by Smith and colleagues in Queen's University Belfast on a monolith taken in the vicinity of Behy court tomb (see photo in Fig. S8a). The sampling location was most likely close to profiles BHY IV and BHY V (Fig. 1b; probably near to BHY V, i.e. the one nearer to the court tomb).

The results of the ${ }^{14} \mathrm{C}$ dating were problematic in that the uppermost date, $3930 \pm 105 \mathrm{BP}$ (from -36 to $-38 \mathrm{~cm}$, fine particulate fraction; the negative depths indicate distance above the mineral soil-peat interface), was the oldest, while the fine particulate and humic fractions of the lowest sample $(-24$ to $-28 \mathrm{~cm})$ yielded distinctly different dates ( $3890 \pm 110 \mathrm{BP}$ and $3245 \pm 70 \mathrm{BP}$, respectively). Smith et al. (1973) concluded that the movement of humic acid in the peat resulted in ages being apparently too young. The sample (bulk sample) from -30 to $-34 \mathrm{~cm}$ also gave a ${ }^{14} \mathrm{C}$ date younger than expected that, according to the investigators, was the result of humic-acid movement in the peat.

Using an age-depth curve based on three dates, i.e. $3890 \pm$ $110 \mathrm{BP}, 3930 \pm 105 \mathrm{BP}$ and a surface point with an estimated date of $1950 \mathrm{CE}$ (peat thickness estimated to be $170 \mathrm{~cm}$ ), it is estimated that peat initiation began at ca. $3350 \mathrm{BCE}$. The pollen data (not published) indicated that, in the basal peat, oak-dominated woodland prevailed and, rather significantly, there is no mention of pine (Smith et al., 1973). The base of the record thus seems to postdate the pine flush in the area (see Sect. 5.1). The peat-mineral soil interface in profile BHY V dates to $2500 \mathrm{BCE}$ which would appear to be a more realistic, even if too young, date for initiation of peat accumulation close to the Behy tomb (see Sect. 5.1).

Smith et al. (1973) suggested that, on the basis of a comparison of the pollen data from the monolith with those from a sample from beneath cairn stones (presumably associated with the tomb), construction of the cairn that is associated with the tomb took place as peat at -27 to $-28 \mathrm{~cm}$ (dating to ca. 2500 BCE) accumulated. From what is known about the age of court tombs (Schulting et al., 2012) and our present understanding of Neolithic and Bronze Age developments in the Céide Fields area, it is doubtful that cairn (and court tomb) construction was so late.

\subsubsection{Pollen analytical investigations at Céide Fields by Moore (1979)}

Moore (1979) discusses pollen profiles that had probably been constructed about a decade before publication, i.e. Behy I from beside the Behy court tomb and Behy II from $2 \mathrm{~km}$ to the west and at lower elevation (profiles Behy I and II are reproduced in Fig. S1a), and a third from Glenamoy (deeper peat; pollen diagram not published). There is no independent evidence of age, but the pollen signature is such that it can be assumed with a high degree of certainty that the base of Behy II predates the start of Neolithic impact and that Behy I starts in the middle to late Neolithic.

Behy I shows high arboreal pollen (AP) levels, including high Pinus values $(\sim 20 \%-30 \%)$, in a few spectra at the base after which non-arboreal pollen (NAP) levels and especially Poaceae (initially), Ericoids (presumably mainly Calluna) and Potentilla-type pollen have increased representation. A Plantago lanceolata curve begins when Pinus starts to decline and continues, though frequently interrupted, until mid-profile where the values increase at first modestly but then substantially towards the top. Profile Behy II is longer $(230 \mathrm{~cm})$ and the base is older. Noteworthy is a major decrease in Pinus together with the first records for cereal-type pollen and $P$. lanceolata near the base of the profile (corresponding to Neolithic landnam followed by increased AP (corresponding to woodland regeneration), including a rise in Pinus (i.e. a pine flush) and then the demise of pine and expansion of grasses and heathers. These later changes are comparable to those recorded in Behy I.

\subsubsection{Pollen analytical investigations at Belderrig by Bourke (1972)}

These investigations resulted in a pollen profile (here referred to as Belderg; for a summary pollen diagram (profile BDG1) see Fig. S1b) from beside a stone wall on peat (wall 3 in Verrill and Tipping, 2010a) that has been dated to the late Bronze Age (it is regarded as the extension of a much earlier wall onto peat; see Sect. 1). The pollen profile is similar to Behy I in that, at the base, AP dominates (mainly Corylus/Myrica). Pinus subsequently increases to achieve $33 \%$ which is regarded as reflecting a pine flush. After that, $P i$ nus decreases to low values and does not recover. Initially Betula expands and then Poaceae. These developments are very similar to those recorded in BHY VI (see results in Sect. 4.1.2) but have little in common with profile BEL by Verrill and Tipping (2010b) which is from less than $250 \mathrm{~m}$ away (see Sect. 2.2.2). Interestingly, P. lanceolata values are low (more or less continuously but generally $<2 \%$ ), and only a few cereal-type pollen grains are recorded which suggests low levels of farming. Perhaps the investigations are 
insufficiently detailed to comprehensively reflect farming activity, the evidence for which, including cultivation ridges, ard marks, lynchets and a saddle quern, points to substantial arable activity. The arable activity may have been confined to the vicinity of the Bronze Age house where the ard marks and overlying extensive cultivation ridges were recorded (see Sect. 1 and Fig. S8b). This is $\sim 190 \mathrm{~m}$ downwind from the profile location which, given that cereal pollen is poorly dispersed, is considerable.

\subsection{Palaeoecological investigations since ca. 1990}

\subsubsection{Investigations at Céide Fields (Molloy and} O'Connell, 1995; O'Connell and Molloy, 2001)

Detailed pollen analytical investigations commenced in 1992 with a view to reconstructing long-term vegetation history, long-term human impact and blanket-bog development at the main stone-wall complex that is usually referred to as Céide Fields. For this purpose, monoliths consisting of blanket peat and underlying mineral soils (BHY III-VI, also monoliths and samples from at and beside the visitor centre), as well as a long core from Glenurla basin (GLU IV) which lies within the field complex, were collected (Figs. 1b and S8a). The main results were published in Molloy and O'Connell (1995). These were later summarised, together with additional details, in a review paper relating to Neolithic impact in Ireland (O'Connell and Molloy, 2001). Since these investigations are still the main evidence for environmental change at Céide Fields, the data are presented below in some detail, together with information that was not available at the time of the earlier publications including additional ${ }^{14} \mathrm{C}$ dates obtained in 2000, loss-on-ignition (LOI; ashing) measurements and tephra investigations. Details regarding results of the tephra investigations, including geochemical analyses, will be published separately.

\subsubsection{Palaeoecological investigations at Belderrig by Verrill and Tipping (2010a, b)}

These authors presented information derived from multidisciplinary investigations relating to the Belderrig field system, including a pollen diagram that spanned ca. 3600-2500 BCE. The dates derived from these publications that we cite below, including the age-depth relationship for the profile, are based on the ${ }^{14} \mathrm{C}$ dates given by the authors that have been recalibrated (the resulting differences are small). Verrill and Tipping (2010b) showed that substantial mineral soil erosion took place after wall construction (in the Neolithic) and that peat initiation was time transgressive, beginning in the basin (wood peat being initially formed rather than blanket bog) and proceeding upslope where blanket-bog peat began to accumulate in the early Bronze Age (ca. $2010 \mathrm{BCE}$ ). Interestingly, Dwyer and Mitchell (1997; see Sect. 2.2.4) also report diachronous peat development at Croaghaun East, to the south of Céide Fields, where peat initiation started distinctly later (at ca. 3800 BP, i.e. 2200 BCE) at a downslope location from the main core. It is suggested that blanket-bog expansion coincided with increasing wetness, and at two locations in Croaghaun East it dates to ca. 4200 BP, i.e. ca. 2900 BCE.

The main features of the pollen diagram BEL by Verrill and Tipping (2010b) include dominance of Alnus (the pollen was so abundant that it was excluded from the pollen sum), little $P$. lanceolata apart from a single spectrum near the base where it achieved 2\%-3\%, exceptionally high Ilex (holly) values (for much of the profile 5\%-18\%), and AP taxa consisting mainly of Corylus, Pinus and Quercus. There is a small peak of Pinus near the top that may reflect a pine flush though it is rather late (ca. 2600 BCE) if it is the classical pine flush (see Sect. 5.1). Cereal-type pollen is not recorded. Caulfield (2018, p. 66), in what appears to be a reference to this pollen profile, points to records of cereal pollen in "the upper levels of the core" which he attributes to "the tillage plots to the west". Only part of the pollen profile may be published in Verrill and Tipping (2010b), which, if correct, is regrettable given the importance of the site. The tillage plots referred to by Caulfield (2018) are presumably those associated with the late Bronze Age house.

On the basis of their investigations, Verrill and Tipping (2010b) draw various conclusions regarding human impact and farming in the area. They suggest that the base of profile BEL, which dates to ca. $3600 \mathrm{BCE}$, captures the final phase of Neolithic farming and that, outside the field system, a partially wooded landscape persisted. In reality, more data are required, including much higher pollen counts, to enable firm conclusions to be drawn regarding Neolithic farming at Belderrig.

Verrill and Tipping (2010b) emphasise the importance of climate rather than human impact as a driver of landscape change including blanket-bog formation. Humification data relating to core BEL suggest particularly low peat humification in the interval 3000-2900 BCE, this trend having set in as early as 3200 BCE. Lower levels of peat humification are interpreted as signalling wet climatic conditions. Low humification and decomposition are regarded as giving rise to low pollen concentrations as a result of faster peat accumulation, which is plausible but additional independent evidence is desirable. Apart from an interruption in the Calluna curve, the curves for bog and aquatic taxa remain steady. This is not what might be expected if the mire surface became substantially wetter. The evidence for increased wetness due to wetter and stormier conditions at Belderrig is not as well founded as implied by Verrill and Tipping (2010b) and indeed does not agree with the evidence derived from the pine timber record for the north Mayo region (see Sect. 5.1).

In Verrill and Tipping (2010a) attention is focussed on the tillage plots (cultivation ridges and ard marks) associated with the Bronze Age house (Fig. S8b). In thin-soil sections, features associated with the cultivation ridges were clearly distinguishable, but it was not possible to be definitive as to whether the cultivation ridges were made using an ard or 
spade. Caulfield (1972) assumes the latter which is plausible on the basis of recent ethnographic parallels (Bell and Watson, 2008; see also photographs in Fig. S8b). The ard marks could not be distinguished in thin sections, nor were they distinguishable in the pollen profile (Verrill and Tipping, 2010a). The unnamed pollen profile, derived from mineral soil and overlying peat samples taken in the area with cultivation ridge and ard marks, is here referred to as BEL-S1. As expected, pollen assigned to cereal-type and weeds of arable or disturbed ground and also P. lanceolata are well represented in the spectra from the mineral soil. Calibration of the only available ${ }^{14} \mathrm{C}$ date, i.e. $2450 \pm 35 \mathrm{BP}$, from the basal peat suggests a terminus ante quem for local peat development of ca. $600-410$ BCE (53\% probability), but an older date cannot be ruled out (26\% probability that the ${ }^{14} \mathrm{C}$ date relates to the interval $750-680 \mathrm{BCE}$ ). Given that the ${ }^{14} \mathrm{C}$ date relates to basal peat and also bearing in mind ${ }^{14} \mathrm{C}$ dates relating to the site that have become available more recently (Caulfield et al., 2011a; Warren, 2018), it is reasonable to conclude that the final phases of tillage as recorded in the pollen record relate to the late Bronze Age. This conclusion is also supported by the lack of Pinus in profile BEL-S1 though it is unclear if Pinus pollen was actually not recorded; it may be that Pinus records were simply omitted from the pollen diagram (Verrill and Tipping, 2010a). The ard marks, originally regarded as possibly Neolithic (Caulfield, 1972), have been assigned to the late Bronze Age by Verrill and Tipping (2010a), a view that appears to be generally accepted (e.g. Caulfield, 2018). In other words, they are probably not much older than the overlying cultivation ridges.

There is evidence that farming, including cereal cultivation, continued at the site before and after house construction (Caulfield, 1973, 2018) and indeed over a considerable period (Verrill and Tipping, 2010a). Interestingly, Verrill and Tipping (2010a) point to soil features that suggest amelioration practices including the addition of domestic waste (ash and animal bone) to the area under tillage.

\subsubsection{Pedological investigations at Belderrig, Céide Fields and Rathlackan by Guttmann-Bond et al. (2016)}

These authors report on multidisciplinary investigations carried out on test-pit profiles from the three key archaeological areas in north Mayo listed in the subtitle above. The main test pits within each area are from locations where there was evidence for arable cultivation, mainly in the form of cultivation ridges and/or ard marks. From Belderrig, accelerator mass spectrometry (AMS) ${ }^{14} \mathrm{C}$ dates $-3563 \pm 30,3649 \pm 30$ and $3091 \pm 29 \mathrm{BP}$ - are provided. These support the idea of activity extending over a considerable duration in the middle to later Bronze Age in the vicinity of the roundhouse. At Céide Fields, test pits were dug near the visitor centre where excavations prior to construction of the centre revealed the presence of ard marks. Here, and also at Rathlackan, the as- sumption is that the sites investigated relate to the Neolithic. Soil-phosphate and bile-acid data suggest low levels of application of herbivore dung. In one test pit at Céide Fields, the chemical evidence suggests human faecal material. Here also extensive cereal cultivation is postulated for areas adjoining the visitor centre. The authors tentatively suggest that animal manure (dung of herbivores) was used to maintain soil fertility, which is interesting in the context of stable-isotope evidence for the use of livestock manure during the Neolithic in Europe (Bogaard et al., 2013) and recent palaeolimnological evidence for major impact by Neolithic and Bronze Age farming on lake systems, possibly involving animal manure, in nearby County Sligo (Co. Sligo; Taylor et al., 2017). The importance of fires in the context of prehistoric farming in north Mayo is emphasised (based on the abundance of mainly fine charcoal), but it was not possible to determine if firing was natural or human-induced.

\subsubsection{Dendrochronology and ${ }^{14} \mathrm{C}$ dating of pine timbers from north Mayo (Caulfield et al., 1998)}

This study reports on the results of a ${ }^{14} \mathrm{C}$-dating programme in the later 1990s that involved sampling and dating of pine timbers from north-west Mayo. The numbers of ${ }^{14} \mathrm{C}$ dates of pine are as follows (Figs. 1, 7 and 8): 19 from Céide Fields (includes six townlands) and 11 (this excludes dates SI-1470, UCD-C47 and C49 that were redated; these are included in Fig. 7 but excluded from Fig. 8) from Belderrig, i.e. Belderg Beg, Belderg More and Geevraun townlands. Additionally, basal peat was dated at Geevraun. From the west of Belderrig - referred to as Erris - there are 17 dates (this excludes a date from intertidal peat but includes two dates of pine stumps by Håkansson, 1974). The above set of pine dates (47 in total) from the north Mayo region shows that pine colonised peat surfaces at various times between ca. 6500 and 1300 BCE but most frequently over a relatively short interval of a few centuries centred on ca. $3000 \mathrm{BCE}$, which may be regarded as an indicative age for pine flush events in western Ireland (this is regarded here as the classical pine flush to distinguish it from other earlier (and also later) pine flushes in Ireland and also Scotland; e.g. Birks, 1975; Bridge et al., 1990; see Discussion). Significantly from a chronological point of view, stumps that were recorded on stone walls in Belderg More and Annagh More townlands provide a terminus ante quem for these walls (see Discussion). The substantial depth of peat underlying several stumps (10 and 5 timbers on $>50 \mathrm{~cm}$ to $\leq 100 \mathrm{~cm}$, and on $>100 \mathrm{~cm}$, respectively) suggests there was already considerable and extensive peat accumulation at or before the late Neolithic and early Bronze Age in the region. This has led Caulfield et al. (1998, p. 638) to conclude that "blanket bog formation in N. Mayo is early and almost certainly unconnected with human activity".

Investigations into the history of pine, involving matching tree rings and investigating pine-pollen concentrations in basal peats, have been carried out by Martin Downes 
with a view to strengthening the chronological framework for blanket-bog development and settlement history, but the results have not been published (Caulfield, 2018, p. 64). Caulfield (1988), referring to Downes' investigations, indicates that the pine trees preserved in peat close to but at a higher elevation than the archaeological site at Belderrig, i.e. in Geevraun townland (Fig. S8b), grew for about a century and are datable to the main pine flush. Caulfield et al. (2013, p. 99) refer to unpublished investigations that rely on "evidence for a pine flush in the pollen sequence" to support the idea that "peat engulfed Céide Hill from the west" which is plausible given the results from pollen cores BHY III-VI (see Sect. 4.1.2).

\subsubsection{Dendrochronology and ${ }^{14} \mathrm{C}$ dating of pine timbers from Garrynagran (Jennings, 1997)}

Garrynagran refers to an area of extensive blanket bog that lies $16 \mathrm{~km}$ to the south of the visitor centre, Céide Fields and within $7 \mathrm{~km}$ of the nearest pine timbers dated by Caulfield et al. (1998). Pollen analytical and dendrochronological investigations were undertaken here in the mid-1990s in the context of a PhD study by Jennings (1997). Part of the main pollen diagram, GRN I, was published in O'Connell and Molloy (2001). The complete pollen profile and also the results from dendrochronological investigations at Garrynagran are presented here (details below).

Core GRN I was taken in Ballynagor townland, $3 \mathrm{~km}$ north-west of Moygownagh and adjoining Garrynagran townland (Figs. 2a and S8c). Garrynagran derives from Garrai na gCrann, i.e. the garden of the trees, which undoubtedly references the many stumps and tree trunks embedded in the extensive bogs in this part of County Mayo. The place name, Garrynagran, is therefore appropriate when referring to this study area.

Two court tombs (other megaliths including standing stones ascribable to the Bronze Age and also pre-bog stone walls) are known about from within $1.5 \mathrm{~km}$ of core GRN I (de Valéra and Ó Nualláin, 1964; see https://moygownagh. ie/, last access: 1 November 2019, for a description of the Blanemore Forest Archaeological Walk; Fig. S8c). The court tombs represent the southern extension of a group of tombs with its main concentration in the area between Céide Fields and Killala and extending south-eastwards but avoiding higher ground (above $\sim 100 \mathrm{~m}$ ) to the west (de Valéra and Ó Nualláin, 1964). Given the close geographical and archaeological relationships to Céide Fields, it is appropriate to present data from Garrynagran here. Also included are ${ }^{14} \mathrm{C}$ dates from pine timbers from Inishbofin (off the west Mayo coast) and the shores of Lough Mask in south Mayo (details in Sect. 4.2.2).

\subsubsection{Other palaeoecological investigations in the wider region}

Profile Patchico (patch in common) refers to a $\sim 5 \mathrm{~m}$ long Holocene pollen profile from a small bog pool $\sim 960 \mathrm{~m}$ south-west of the Bronze Age house site at Belderrig (Hawthorne and Davis, 2013; Fig. 1c). The record starts in the early Holocene shortly before Corylus expands. Corylus (this pollen taxon may include Myrica) and Pinus dominate the AP component until mid-profile when Pinus declines. This decline is presumably the regional decline in Pinus that occurs shortly after ca. 3000 BCE. According to Hawthorne and Davis (2013), the elm decline, which is not a distinct feature, may be reflected in changes recorded $\sim 20 \mathrm{~cm}$ lower (local pollen assemblage zones (PAZs) PatcIII-Patc-IV boundary) but it may also be reflected still lower in the profile (the available ${ }^{14} \mathrm{C}$ dates, i.e. $7680 \pm 50$ and $6070 \pm 30 \mathrm{BP}$, relating to the lower part of the profile, are not helpful in this regard). High ericoid values (curves for both Calluna and Ericoids (unspecified)) are recorded in the lower and upper parts of the profile but surprisingly few Cyperaceae are recorded. The record from the upper part presumably reflects the open bog-covered landscape of recent times, while that from the lower part may reflect heathy vegetation, at the sampling site and/or perhaps also in the wider area, that coexisted with substantial tree cover. Records for cereal-type pollen are not provided (so we assume none were recorded), and $P$. lanceolata pollen is poorly represented which, at face value, suggests that farming was never important, at least near the site. This is rather at variance with the archaeological and other palaeoecological evidence (e.g. Verrill and Tipping, 2010a, b; also Bourke, 1972). More detailed analyses are required before firm conclusions regarding local vegetation, landscape dynamics and farming history can be drawn.

Sediments from Cregganmore Lake $(\sim 350 \times 220 \mathrm{~m}$; $6.6 \mathrm{ha}$ ), situated $4 \mathrm{~km}$ to the south-west of the Bronze Age house site at Belderrig (Fig. 1a), have been the subject of various investigations. A pollen profile by McKeever (1984) is summarised in McKeever and Davis (2013). The $\sim 7.5 \mathrm{~m}$ long profile begins in the Late Glacial Interstadial and probably extends to recent or near-recent times. Apart from three ${ }^{14} \mathrm{C}$ dates from the basal part, an independent chronology is lacking. The pollen data suggest that hazel, pine and oak were the main trees for most of the Holocene. P. lanceolata or other anthropogenic pollen indicators (there are no records for cereal-type pollen) are poorly represented, so it is not possible to draw conclusions regarding human impact, apart from suggesting that it seems to have been unimportant. In subsequent investigations, chironomid, geochemical and geophysical analyses and ${ }^{14} \mathrm{C}$ dating (10 dates) were carried out on new cores, 6-7 m long, with a view to exploring impact of climate variability on long-term human activity (Holmes et al., 2013). At least half the core is pre-Holocene, so the resolution for the period of greatest interest, i.e. the Holocene, is low. Apart from suggesting that the chironomid- 


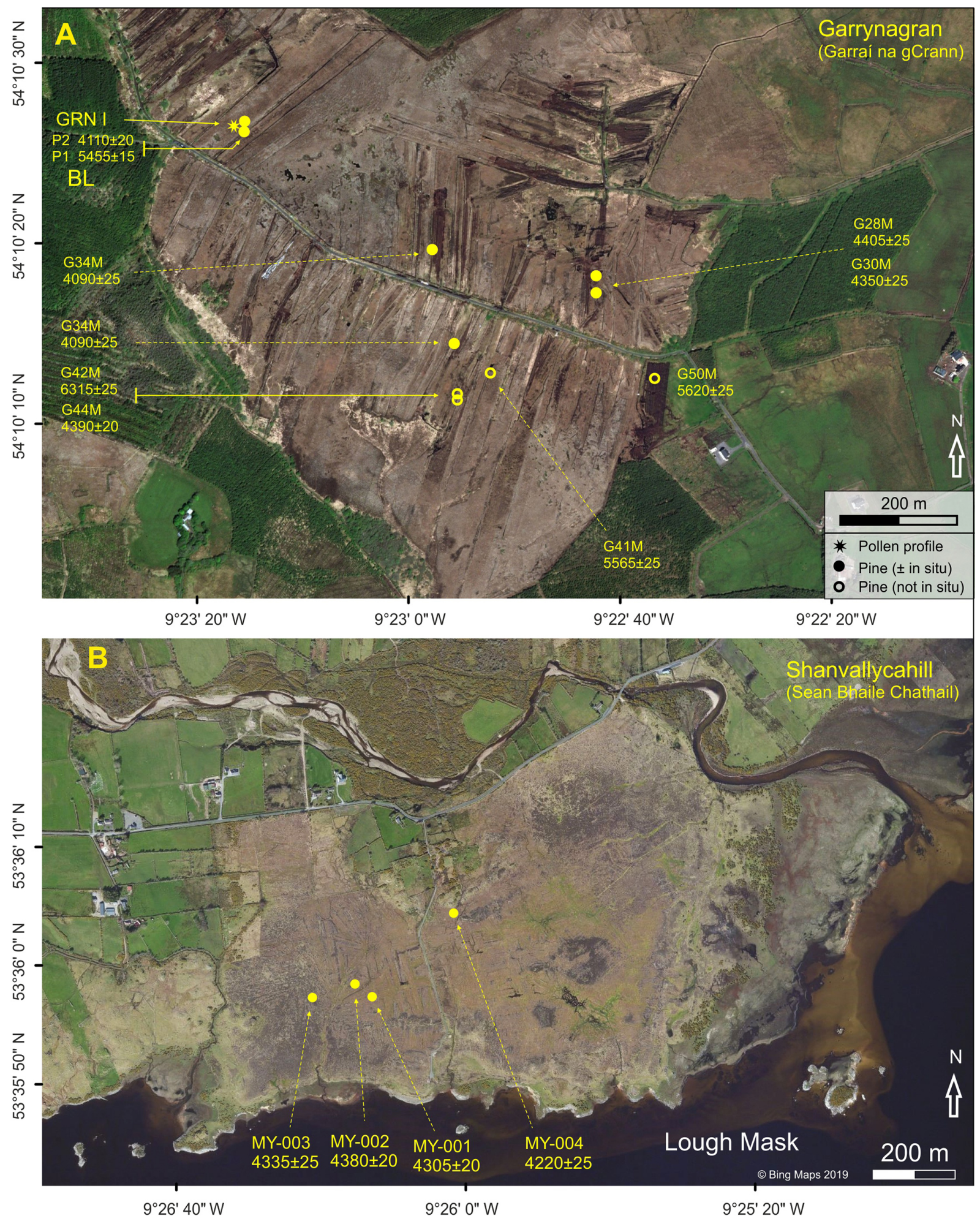

Figure 2. Locations of (a) ${ }^{14} \mathrm{C}$-dated pine timbers and the pollen profile GRN I at Garrynagran (BL is Blanemore) and (b) ${ }^{14} \mathrm{C}$-dated pine timbers at Shanvallycahill. Non-filled circles are used to indicate timbers that were not in situ when sampled (1994). The aerial photograph in (a) (accessed using ArcGIS, 22 May 2019) reflects quite well the situation at the time of sampling, especially the extant bog (both exposed cutover surfaces and the relatively intact bog north of centre of the photo). Dark green indicates young conifer plantations on cutover bog. The aerial photograph in (b) is from Bing Maps (@Microsoft), accessed 22 May 2019. 
derived Holocene mean July temperature was similar to that of today (an average of $14 \mathrm{vs} .14 .9^{\circ} \mathrm{C}$ at nearby Belmullet in the period 1981-2010), no firm conclusions were reached regarding climate during the Holocene. The authors cite Caseldine et al. (2005) and O'Connell and Molloy (2001) as indicating that "the decline of Neolithic agriculture was linked to an extreme climatic event ca. 5200 cal BP'. O'Connell and Molloy (2001) nowhere suggest this.

A peat profile from Croaghaun East, which lies $12 \mathrm{~km}$ south of Céide Fields and $5 \mathrm{~km}$ west of Garrynagran (Fig. 1a), was investigated by Dwyer and Mitchell (1997) with a view to documenting local expansion of blanket bog which they show to be diachronous. The profile spanned the interval ca. 4700-2270 BCE. In core CRST1, seven tephra layers were detected including two closely spaced layers that date to ca. $2100 \mathrm{BCE}$, i.e. approximately the Hekla 4 (H4) eruption. The chemical composition of these two layers was similar, though not in all respects, to H4. Interestingly, these tephra layers lay above the decline of Pinus (dated to ca. $2200 \mathrm{BCE}$ ), and so it is concluded that tephra deposition was not implicated in the decline of pine. The pollen data suggest that, while the vegetation on mineral soil was unaffected, the bog surface became distinctly wetter at the time of tephra deposition. This too is the time when local blanket-bog expansion occurred (Dwyer and Mitchell, 1997). The authors, however, refrain from making a causal connection between tephra deposition and increased bog wetness but, on the other hand, link the pine decline to a transition from dry to wetter bog-surface conditions that preceded tephra deposition. $\mathrm{Hu}$ man activity (based on the $P$. lanceolata curve) registers at the base of the profile (ca. 3100 BCE) and again towards the top, i.e. after the pine decline. The authors saw no evidence to connect expansion of blanket bog with human activity.

From Achill Island, Caseldine et al. (2005) report on investigations of a pronounced and extensive silty layer in cores from blanket-bog contexts (Fig. 1a; three short profiles are presented that are here collectively referred to as Dooega). The pollen profiles show the typical regional pattern for Pinus in the mid-Holocene, namely strongly elevated pollen values indicative of a pronounced pine flush, which is preceded by (in one of the profiles it coincides with) the well-developed and widespread silty layer that the authors date to ca. $3200 \mathrm{BCE}$. The silty layer is regarded as indicative of slope erosion caused by an extreme weather event, most likely a storm. Dry conditions, however, which facilitated the pine flush, persisted for a considerable period (till ca. 2850 BCE) after the extreme event. The authors suggest increasing wetness from ca. $2850 \mathrm{BCE}$ onwards, that led to pronounced wetness at and after ca. 2000 BCE (see Discussion). It is suggested that there was a long period (500 years) characterised by dry and warm conditions in the early part of the fourth millennium BCE during which Neolithic farming was introduced and initially expanded strongly in Ireland.

Caseldine et al. (2005) also provide a useful overview of climate-change events in Ireland and elsewhere in Europe at about this time. The evidence includes particularly narrow tree rings in Irish oaks centred on 3200 BCE (Baillie and Munro, 1988) and the cessation of varve formation in the sediments at An Loch Mór (dating to ca. 3300 BCE; cf. Holmes et al., 2019; see also Discussion).

In contrast to the pollen profiles from Achill, pollen profiles from four lakes that lie east of Achill in Co. Mayo, i.e. L. Aisling, L. Clevala, L. Anaffrin and L. Corslieve (Fig. 1a), provide no evidence for a pine flush though Pinus is well represented in the upland lakes, L. Corslieve and L. Aisling (Bradshaw and Browne, 1987). Nor does a pollen profile from L. Doo, $11 \mathrm{~km}$ south-west of Carrownaglogh, record a pine flush (O'Connell et al., 1987), probably because of a lack of bog development in the vicinity of the lake.

\section{Methods}

Methods as applied in the investigations relating to Garrynagran are presented, and information is also given as regards investigations relating to cores and monoliths collected at Céide Fields, especially where such information is not already available in Molloy and O'Connell (1995).

\subsection{Fieldwork at Garrynagran}

The sampling site lies in an area of extensive cutover peat (much of the uppermost peat - estimated to be $\geq 1 \mathrm{~m}-$ had been cut away) where, in the early 1990s, there were numerous exposed pine stumps on the cutover bog surface and in drainage channels and also uprooted stumps collected into clearance heaps (Fig. 2a). At the peat face where the monolith GRN I was taken, pine stumps were exposed by peat cutters. These stumps were well spaced out along a drain beside the peat bank where they protruded above the water table (Fig. S8c). The nearest stump to the sampling site $(\sim 2 \mathrm{~m}$ distant) related to a depth of $\sim 140-150 \mathrm{~cm}$ in the profile. At a higher level on the exposed peat face and immediately to the side of monolith GRN I at a depth of $\sim 55-60 \mathrm{~cm}$ from the cutover surface, there was a small and apparently isolated pine stump (Fig. S8c).

Timbers, which were exposed by peat cutting (many were obviously in situ (Fig. S8c); some lay on the cutover surface and were presumed to be more or less in situ; others were gathered in piles and so exact find contexts could not be ascertained), were sampled for dendrochronological investigation as follows. Where possible two slices, each some centimetres thick, were removed from as high up the stem as possible in the case of a stump, and from an area clear of side branches and close to the stump where tree trunks were available. In all, 29 timbers, including three oak trunks, were sampled. 


\subsection{Laboratory methods}

\subsubsection{Pollen analytical methods}

In the case of pollen profile GRN I, sampling for pollen, sample preparation, and pollen identification and counting were carried out according to standard procedures as implemented in the Palaeoenvironmental Research Unit, National University of Ireland Galway (NUIG; Molloy and O'Connell, 1995; Jennings, 1997).

All available pollen counts from Garrynagran and Céide Fields were brought into Excel files and replotted in pollendiagram format using CountPol or Grapher. Short and long profiles were plotted in histogram and curve formats, respectively. A total terrestrial pollen (TTP) sum and a cut-off size for cereal-type pollen of $40 \mu \mathrm{m}$ (provided the relevant pore and annulus size criteria were fulfilled; see Beug, 2015) were used. Bog taxa (Cyperaceae, Ericoids, etc.) and other taxa such as non-pollen palynomorphs (NPPs) were excluded from the pollen sum (PS). High pollen counts were achieved in most samples. The main exceptions were the pre-elm decline samples in GLU IV and a few levels in GRN I (which were difficult to count due to much debris and low pollen concentration). The average pollen count in respect of the TTP taxa and the associated standard deviation is given in the relevant pollen diagrams. Percentage values for the taxa excluded from the PS are expressed relative to the PS + the sum of taxa relating to the relevant category, e.g. bog taxa, aquatic taxa and NPPs. For calculation purposes, Sphagnum and micro-charcoal particles, etc. are regarded as constituting single-component groups. The datasets are available in the palaeo-database PANGAEA (O'Connell et al., 2020).

In the case of short pollen profiles from Behy (published in Molloy and O'Connell, 1995), minor taxa - e.g. Quercus, Ulmus, Fraxinus and Taxus, and also Alnus and Salix - were summed with a view to reducing the complexity of the diagrams and providing greater visibility for taxa that are of significance for palaeoenvironmental reconstruction appropriate to this paper.

\subsubsection{Loss-on-ignition and tephra investigations}

LOI measurements were carried out using standard methods (cf. Heiri et al., 2001). Tephra investigations involved the systematic ashing of $4 \mathrm{~cm}$ thick blocks of peat taken from monoliths and cores collected at Céide Fields and Garrynagran. The ash so obtained was microscopically searched for tephra shards (cryptotephra). Where concentrations of tephra shards were identified, the peat was resampled by taking $1 \mathrm{~cm}$ thick slices. The samples were chemically treated to extract tephra shards. Details will be published elsewhere. For the sake of completeness, the location of tephra layers within the relevant profiles are indicated (see Results).

\subsubsection{Dendrochronological investigations}

Dendrochronological investigations relate to pine and oak samples from Garrynagran and are fully described in Jennings (1997). Two and, where possible, three radial sections were cut from the timber discs using a bandsaw, avoiding where possible side branches, distortion due to root protrusions and excessive reaction wood. The wedge-shaped samples were pared so as to be able to clearly see the ring boundaries that were highlighted by applying chalk dust.

Ring-width measurements were carried out by placing the wood sample on a moving stage controlled by a screw thread. A Wild M8 binocular microscope with a cross-hair graticule was used, in conjunction with the measuring stage, to measure the distance between ring boundaries. Ring thickness was measured to the nearest $0.01 \mathrm{~mm}$ by a digital counter (Heidenhain bidirectional counter VRZ 405) and the values were input directly into a PC. In instances where, after measuring three radii for a particular timber, problems connected with splitting, missing and false rings remained, further radii - up to six radii in some cases - were measured. In some instances, problems were solved by paring larger areas in the region where problems were identified. Also, all wedgeshaped radial sections from problem timbers were prepared, and problem rings were then traced around the circumference of the timber. This normally facilitated the recognition and measurement of annual rings with a high degree of certainty. Though pine is considered to be not as amenable to dendrochronological investigation as oak, $P$. sylvestris has limited occurrence of missing and double rings compared with other conifers such as juniper (Fritts, 1976).

Cross-dating between trees was attempted visually, by matching the graphed plots of the ring-width measurements, and also statistically, using the cross-dating programs CROS (Baillie and Pilcher, 1973) and CROS84 (Munro, 1984). The latter program provides a more rigorous test of synchroneity and was mainly used. Where anomalies were identified, these were overcome by further replication of measurements and examining the full cross section of the particular timber. The most reliable matches, i.e. those that yielded the highest $t$ values at long overlaps, were used to build up groups of trees with overlapping ring series. A significant match was where $t$ was $\geq 3.5(p=0.01)$. Groups of trees that showed satisfactory cross-dating (both visually and with self-consistent, significant $t$ values, i.e. above 3.5) were combined into working chronologies.

Once all potentially matching trees had been identified and any inconsistencies eliminated, a mean master chronology was constructed. The mean master was extended by the addition of other mean ring series that matched. This process was continued until no further ring series reliably cross-matched with the existing mean masters (details in Jennings, 1997). Before a working master chronology or a site mean was produced, individual series were standardised (Graybill, 1979) 
so as to remove long-term trends in the data such as those related to the age of a tree.

Samples from three long oak trunks (Fig. S8c) that lay on the cutover peat surface (presumed to be close to where they had been preserved) were measured and matched to the Belfast oak chronology by David Brown, Queen's University Belfast.

\subsubsection{Radiocarbon dating}

Peat samples consisted of peat slices, normally 1 and $2 \mathrm{~cm}$ thick in the case of peat monoliths and core GLU IV, respectively. The bulk peat samples were dated by the conventional ${ }^{14} \mathrm{C}$ dating method. ${ }^{14} \mathrm{C}$ dates were calibrated using OxCal version 4.3 (Bronk Ramsey, 2009) and the default ${ }^{14} \mathrm{C}$ calibration curve, IntCal13.14C (Reimer et al., 2013). Agedepth relationships for the peat profiles were constructed using Clam version 2.2 (Blaauw, 2010; http://www.chrono.qub. ac.uk/blaauw/clam.html; downloaded 22 August 2017) and the IntCal13.14C calibration curve. In all instances, several curve-fitting options were tried (linear and polynomial regressions and various spline-fitting options). Usually, many of the options gave results that were obviously unrealistic and so were rejected. The option that gave what was regarded as the most realistic result was accepted.

Pine timbers from Garrynagran were sampled by taking wood from a specific group of rings (details in Fig. 9) that were dendrochronologically investigated (four and two ${ }^{14} \mathrm{C}$ dates are from timbers included in $\mathrm{P} 1 \mathrm{M}$ and $\mathrm{P} 2 \mathrm{M}$, respectively, i.e. the floating pine chronologies referred to as GRN P1M and GRN P2M by Jennings, 1997). The samples - 10 in all from dendrochronologically investigated timbers (two of these timbers could not be matched) and two timbers from pine stumps beside peat core GRN I - were dated by the conventional ${ }^{14} \mathrm{C}$ dating technique. The midpoint from the calibrated age range of ${ }^{14} \mathrm{C}$ dates from timbers $\mathrm{G} 30$ $(4350 \pm 25 \mathrm{BP})$ and G50 $(5620 \pm 25 \mathrm{BP})$ was used to fix the floating chronologies P1M and P2M, respectively (Jennings, 1997). These dates were chosen because they relate to steep parts of the calibration curve, and so the uncertainty attached to their calibrated age is correspondingly small.

\section{Results}

The main pollen analytical results are presented in pollendiagram format. As regards the long pollen profiles, GLU IV (Glenulra) and GRN I (Garrynagran), percentage pollen curves (all but a few minor curves), selected pollen concentration curves and macrofossil data (sievings from pollen samples) are presented (Figs. 3-6). Short pollen profiles, i.e. BHY series (BHY III-VI), CF I and CF III and pollen data relating to plough marks, are presented in Figs. S3-S7. Where histograms are used to show pollen data, "+", i.e. a record outside the pollen count, is indicated by a small value $(0.05 \%)$ rather than "+".
Graphs showing age-depth relationships for the various cores are presented in Fig. S2. In the age-depth plots pertaining to the various pollen profiles, the dates used and other details including stratigraphy are indicated. Details of all ${ }^{14} \mathrm{C}$ dates relating to pollen and pine timbers are available in Table S1b, c.

\subsection{Céide Fields}

\subsubsection{Core GLU IV (long core from Glenulra basin) (Figs. 3, 4)}

This, the main pollen profile from Céide Fields, has an optimal location within the main Céide Fields complex (Fig. 1). It is the longest and most detailed pollen profile and has the greatest temporal span (>6800 BCE-700 CE). Furthermore, its chronology is well constrained especially in the middle and upper part of the profile, i.e. the most pertinent parts. The age-depth model is derived from a fifth-order polynomial regression curve that uses $20{ }^{14} \mathrm{C}$ dates (two ${ }^{14} \mathrm{C}$ dates are regarded as outliers and so were not used; Fig. S2b).

The main features of profile GLU IV are summarised below and in Table S2a. Given the small size of the peatfilled basin, especially in the early and mid-Holocene when peat accumulation within the basin was limited, the regional pollen signal is assumed to derive mainly from a $\sim 1 \mathrm{~km} \mathrm{ra-}$ dius of the basin. With increasing distance from the basin, the reflection of developments are expected to decrease exponentially in the pollen record (Jacobson and Bradshaw, 1981; Gaillard et al., 2008). In the accounts that follow every effort is made to distinguish between developments in the basin (local, i.e. on the mire surface) and the surrounding landscape (regional, i.e. initially on mineral ground and later on mineral and peaty soils as blanket bog expanded) though this is not always possible given the uncertainties connected with origins of pollen such as those of grasses and bog taxa generally.

Early Holocene development is reflected in the basal part of the profile (PAZs 1-4). Chronological control is weak in this part of the profile (Fig. S2b). The only available ${ }^{14} \mathrm{C}$ date $(5100 \pm 80 \mathrm{BP})$ relates to the upper part of the interval and is clearly an outlier. It is obvious, however, that the record begins relatively early in the Holocene and probably earlier than 6800 BCE. Particularly noteworthy are the high Pinus values. Stumps were frequently encountered during trial corings at about this depth in the basin, and pine wood (pine tracheids) was noted in the pollen samples. The peat-filled basin, which would have been much more limited in extent than today, appears to have supported pine woodland at this time. Calluna, which is strongly represented at the top of PAZs 2 and 3, declines. Given that Calluna pollen is poorly dispersed (Moore et al., 1986), it is probable that ling growing in the basin (it declines as pine expands) rather than on the surrounding mineral ground is reflected here. The precise composition of the woodlands on mineral soil is uncertain but it is likely that, as well as pine, hazel and birch, small 


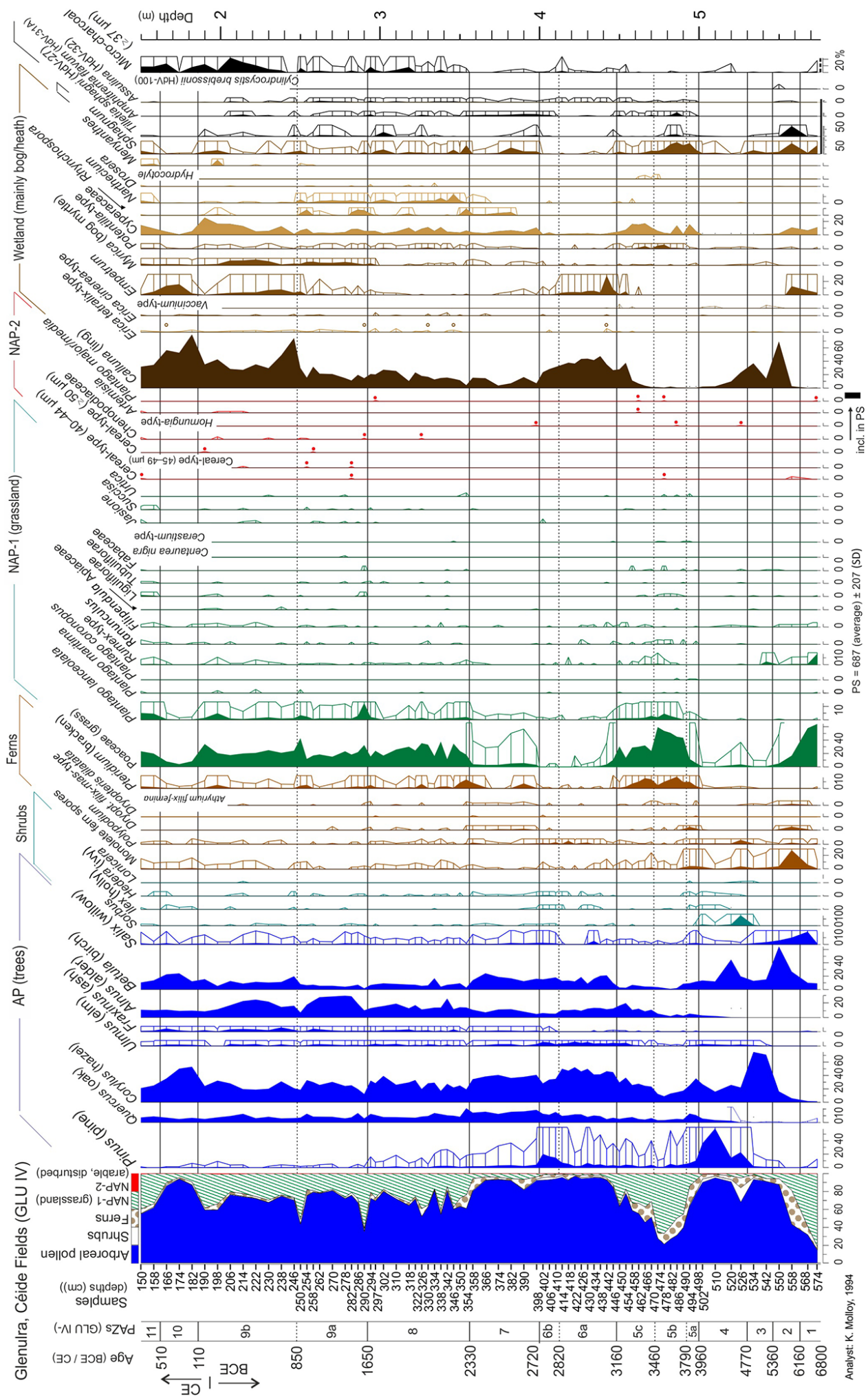

Figure 3. Percentage pollen curves, profile GLU IV (complete profile), Glenulra basin. All curves are drawn to the same scales, except curves with a thick line above the $x$ axis which are drawn to a reduced scale (thick continuous and dashed lines indicate $\times 0.2$ and $\times 0.5$, respectively). Silhouettes show values $\times 10$. A circle (non-filled) is used to indicate records for epidermal cells of Erica tetralix seeds. A filled circle is used to emphasise small values in the case of NAP-2 taxa, i.e. taxa of arable or disturbed habitats. PAZs and PAZ-boundary ages (derived from the age-depth curve) are indicated. 


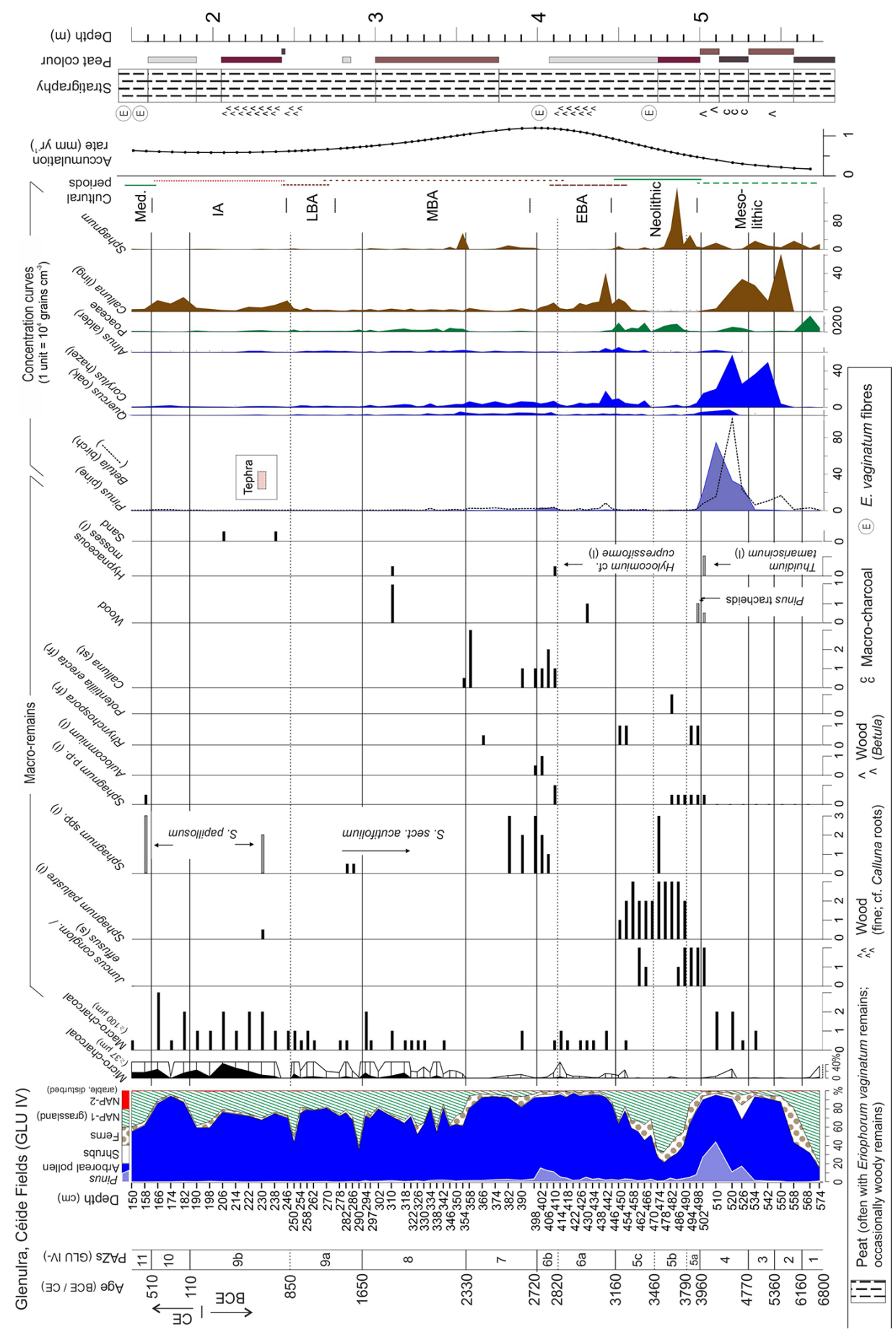

Figure 4. Percentage composite pollen curves, macro-remains and other data including concentration curves for the main taxa, profile GLU IV (complete profile). Cultural periods (as pertain to Ireland; main sources: Waddell, 2010; Aalen et al., 2011; EBA, MBA and LBA: Early, Middle and Late Bronze Age, respectively; IA: Iron Age; Med.: Medieval), peat accumulation rate and stratigraphy are shown. Bars with grey to dark infills indicate peats that are darker than usual to distinctly dark; bars with brown to reddish-brown infills indicate peats with such colours; no bars indicate that the peat does not have distinctive coloration. The abundance of macro-remains is indicated as follows: 3, abundant; 2, frequent; 1, occasional; and 0.5, rare, i.e. +. Macrofossil parts are indicated as follows: (fr) fruit, (l) leaf, (s) seed and (br) branch; br is in Fig. 6 only. Concentration curves are plotted to the same scale ( $x$ axis) except for Sphagnum where the scale is halved with respect to the other curves. PAZs and PAZ-boundary ages (derived from the age-depth curve) are indicated. 


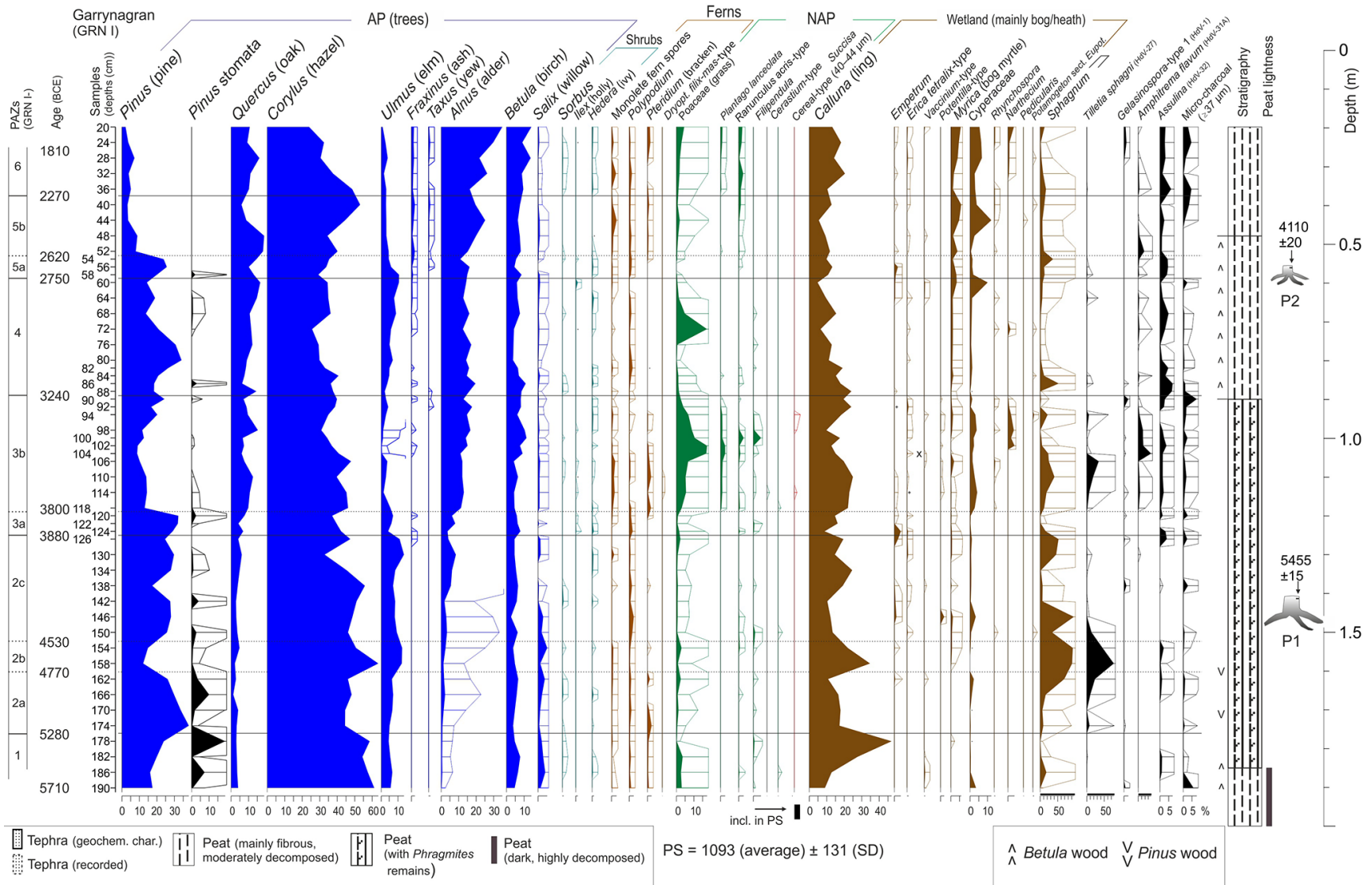

Figure 5. Percentage pollen and related data for profile GRN I, Garrynagran. All curves are drawn to the same scales, except curves with a thick line above the $x$ axis which are drawn to a reduced scale $(\times 0.2)$. Silhouettes show values $\times 10$. Depths are with respect to the cutover surface at the sampling point $(\sim 1 \mathrm{~m}$ of peat removed by turf cutters). A dot indicates a low percentage value where that may not otherwise be obvious. The " $\times$ " symbol indicates the presence of epidermal cells of Erica tetralix seeds. Two pine stumps from beside the peat core (P1 and P2) and ${ }^{14} \mathrm{C}$ dates derived therefrom are indicated. Note that pine stomata percentages are calculated with respect to TTP; i.e. they are excluded from the pollen sum.

populations of oak and elm, willow, rowan, holly, ivy, and honeysuckle were present, all of which are represented in the pollen record (Fig. 3; also Molloy and O'Connell, 1995). The presence of blanket bog in the vicinity of the basin (as distinct from the basin peat) so early in the Holocene cannot be ruled out given the evidence for such a presence provided by pine timbers (see Sect. 4.2.2).

PAZs 5-11 reflect vegetation dynamics within the basin and wider regional contexts. Several influences that vary over time are undoubtedly at play. These include natural processes, e.g. species competition, pedogenesis and climate change, as well as human impact arising mainly from farming activity. Developments in the surrounds of the basin, and especially landscape openness and the role of tall woody species, are, during this time, primarily determined by human activity. This activity is reflected mainly by the NAP component, and especially Poaceae and P. lanceolata. The major expansion of NAP, including Poaceae and P. lanceolata and also Pteridium, and the correspondingly severe de- cline in AP indicate an intensive landnam, i.e. more or less total woodland removal at least in the general vicinity of the basin. Landnam is at its most pronounced in the interval 3790-3460 BCE (PAZ 5b) and is maintained, but with less intensity, during the following three centuries (PAZ 5c). In the period 3160-2790 BCE (PAZ 6a), woodland (mainly hazel, oak, birch and alder, and small amounts of elm and pine) more or less fully regenerates, a development facilitated by greatly reduced human impact. This phase of development culminates in a small increase in Pinus that is regarded as reflecting the regional (also in the vicinity of the basin) pine flush (PAZ 6b, 2820-2720 BCE). A small increase in P. lanceolata (also Corylus declines) points to a resumption of human activity at this time.

As regards the initiation and spread of blanket bog, bog expansion cannot easily be traced in profile GLU IV since pollen of local mire origin, i.e. within the basin, is expected to dominate and, indeed, is probably dominant in the wetland pollen component. Pollen from any blanket-bog con- 


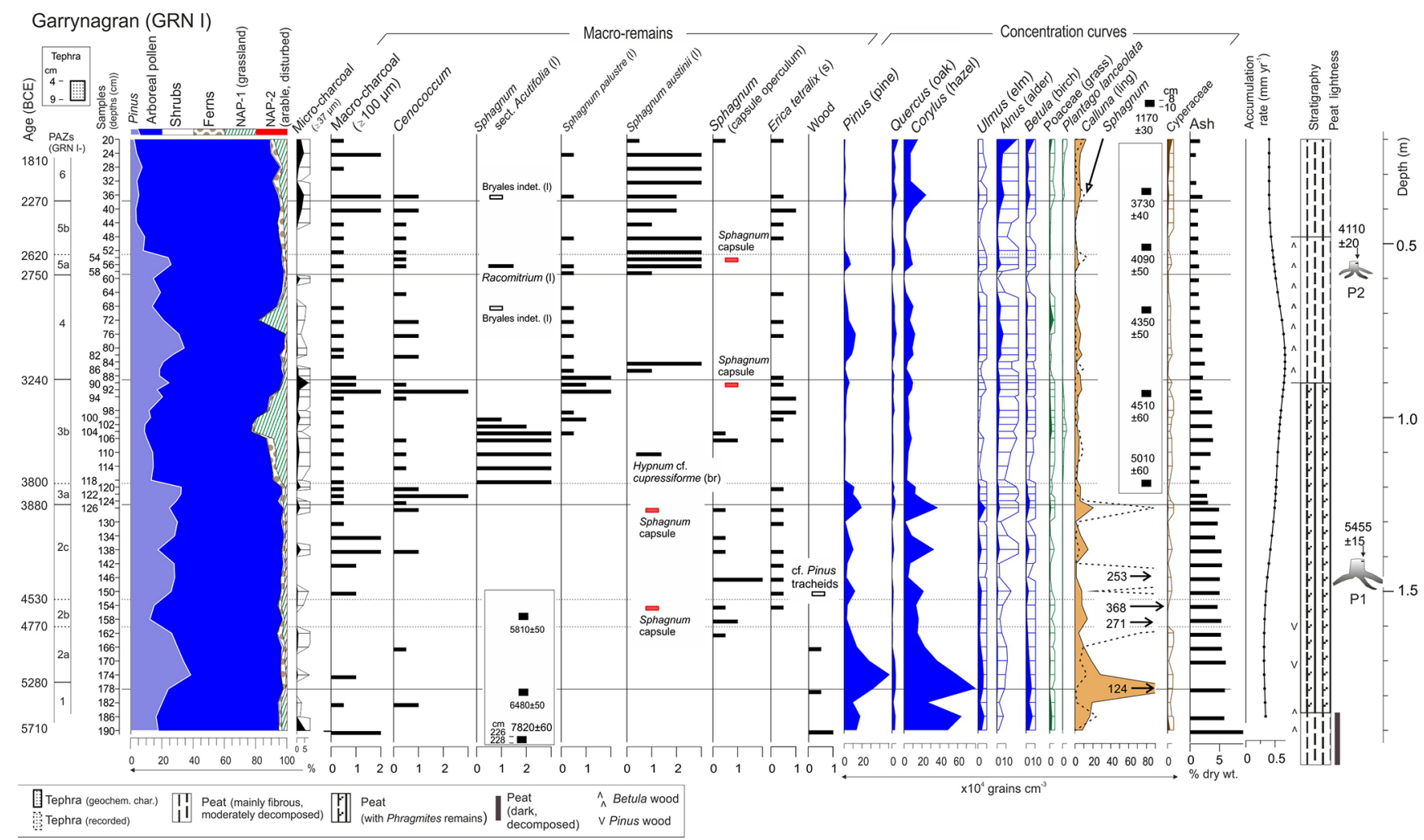

Figure 6. Percentage pollen (composite diagram), macrofossils, pollen concentration (main curves) and other data for profile GRN I, Garrynagran. Silhouettes show values . Abundance of macro-remains is indicated as follows: 3 , abundant; 2 , frequent; 1 , occasional; and 0.5 , rare, i.e. + . Concentration curves are plotted to the same scale ( $x$ axis) except for Sphagnum where the scale is halved with respect to the other curves. For other conventions, see Fig. 4.

texts present in the surrounds would thereby be masked. An intriguing aspect is the possibility that increased mire wetness in the basin (cf. Cyperaceae, Sphagnum and Hydrocotyle (marsh pennywort)), coinciding with landnam, is the result of increased runoff that follows on from large-scale woodland clearance (see Discussion).

High values for Calluna and Empetrum in PAZ 6 (3160$2720 \mathrm{BCE})$ probably reflect ling and crowberry growing locally in the mire basin where dry conditions appear to have prevailed at this time. Given that woodland had regenerated and was dominant, it is unlikely that pollen from pockets of blanket bog in the wider landscape is reaching the coring location in any appreciable quantity.

In the interval 2720-2330 BCE (PAZ 7), i.e. in the late Neolithic, human activity consistently registers, but it is not until the transition to the Bronze Age (PAZ 8) that there is a distinct increase in farming that results in a decrease in woodland and especially a decline in birch, hazel and oak. Fire too increases in importance (cf. micro- and macro-charcoal curves in Figs. 3 and 4, respectively). This strong level of human impact is maintained until $110 \mathrm{CE}$ (particularly high impact in ca. 1650, 850 and the final century BCE; pine ceases to have any importance - locally at least it is probably ex- tinct - from $1650 \mathrm{BCE}$ ) when there is a lull in activity that is regarded as the Late Iron Age Lull. This lasts until the beginning of the sixth century $\mathrm{CE}$ when an upsurge in farming associated with the early medieval period registers (PAZ 11). From $850 \mathrm{BCE}$ onwards, the mire surface appears to have been particularly dry. Calluna is strongly represented, indicating that ling is dominant, and pollen records for hygrophilous plants, such as Narthecium and Rhynchospora, more or less cease.

\subsubsection{Short pollen profiles from Céide Fields}

Short pollen profiles from five sites within the Céide Fields complex are presented in Figs. S3-S7. Age-depth curves are given in Fig. S2a. Each profile is independently zoned, mainly on the basis of careful visual inspection of the pollen percentage curves (zones are similar to those in Molloy and O'Connell, 1995). A zone boundary is always placed at the peat-mineral soil horizon to emphasise this important lithological boundary.

In the headings used below, the profile name and the time span reflected in the particular profile are indicated. Estimated ages are also given as follows: the age of the base of the profile in brackets where mineral soil has been pollen 
analysed, followed by the time span represented by the pollen spectra from the overlying peat. In the Discussion, the ages as assigned below to the individual profiles are further considered and, in some instances, modified in the light of the dataset as a whole.

\section{BHY III, [ $\geq 2700] 2700-250$ BCE, i.e. late Neolithic to mid-Iron Age}

The age-depth curve for BHY III is a smooth spline curve (smooth factor $=0.3$ ) that is based on five of the available seven ${ }^{14} \mathrm{C}$ dates (Fig. S2a). The ${ }^{14} \mathrm{C}$ dates $3360 \pm 50 \mathrm{BP}$ (Gd$7147)$ and $3290 \pm 60 \mathrm{BP}(\mathrm{Gd}-7148)$ (both relate to peat from -6 to $-7 \mathrm{~cm}$ ) have not been included in the analysis as, from the beginning, they were regarded as suspect. The other ${ }^{14} \mathrm{C}$ dates serve to confirm that these dates are indeed erroneous. Curve fitting that included a surface-age estimate $(180 \mathrm{~cm}$ of peat, i.e. $50 \mathrm{~cm}$ added to compensate for peat shrinkage; top regarded as dating to $1950 \mathrm{CE}$ ) was attempted but the agedepth curves that resulted were regarded as unrealistic and so were discarded. Of the BHY series, it is only in this profile that no tephra was recorded.

The pollen data (Fig. S3) indicate that prior to peat growth, and probably for some decades before peat developed, i.e. in the late Neolithic and early Bronze Age, grassland with an ever-increasing heath (ling) component dominated at the sampling site. Peat initiation is estimated to have begun by ca. 2700 BCE. The high Pinus pollen values are presumed to reflect the regional pine flush. A nearby pine stump, on the basis of its stratigraphical position within the peat (we do not have a ${ }^{14} \mathrm{C}$ date for this stump), may be contributing to the elevated Pinus pollen values. According to the age-depth model, the pine flush had ended by ca. 2210 BCE (subzone 2a-2b boundary), but birch (also Sorbus, presumably $S$. aucuparia (rowan)) continued to be important, and farming activity remained at a modest level (low P. lanceolata values). At ca. $1500 \mathrm{BCE}$, there is a switch to a grass-dominated landscape with few trees (little or no pine or birch) or tall shrubs locally and probably also at a regional level (see PAZ GLU IV-9a).

BHY IV, [ $\geq 2400] 2400$ BCE-20 CE, i.e. early Bronze Age to late Iron Age

The age-depth curve for BHY IV is a smooth spline curve (smooth factor $=0.1$ ) that is based on the three available ${ }^{14} \mathrm{C}$ dates (Fig. S2a). Two ${ }^{14} \mathrm{C}$ dates are from near the base and so the lower part is chronologically well constrained. The agedepth model indicates that peat had begun to accumulate by 2400 BCE.

The basal part of the profile (PAZs 1 and 2) reflects the local situation as peat began to accumulate (Fig. S4). Birch is locally dominant; there is a small amount of hazel, but tall canopy trees, including pine, are rare and probably not locally present. From 2000 BCE, i.e. early in the Bronze Age (base of subzone 3a), birch is replaced by grasses probably as a result of increased farming pressures that are maintained until ca. $600 \mathrm{BCE}$. In subzone $3 \mathrm{~b}$, the high values for both Poaceae and Calluna are probably best ascribed to local vegetation on shallow peat that was dominated by grasses, e.g. Molinia caerulea, and ling (Calluna).

BHY V, [ $\geq 2600]$ 2520-210 BCE, i.e. late Neolithic/Chalcolithic to mid-Iron Age

The age-depth curve for BHY V is a smooth spline curve ( smooth factor $=0.2$ ) that is based on the five available ${ }^{14} \mathrm{C}$ dates and a surface age estimate (peat thickness $180 \mathrm{~cm}$, i.e. $50 \mathrm{~cm}$ added to compensate for peat shrinkage; top regarded as dating to $1950 \mathrm{CE}$ ) (Fig. S2a).

The pollen spectra from the mineral soil (BHY V-1) and immediately overlying peat indicate woody vegetation dominated by birch. Sorbus (probably rowan), holly, ivy and honeysuckle were common. Pine was present regionally, but there is no evidence for a pine flush at least near the site (Pinus at only $\sim 1 \%-2 \%$ ) (Fig. S5).

According to the age-depth model, peat initiation at this location began at $2500 \mathrm{BCE}$. Replacement of birch by grassdominated vegetation occurred at $2000 \mathrm{BCE}$. This is somewhat earlier (two centuries) than at nearby BHY IV but about a millennium earlier than at BHY III. The age ascribed to the Betula to Poaceae transition at BHY V may be too old. Contiguous ${ }^{14} \mathrm{C}$ samples give rather different ages. This and the very sharp change in pollen composition at the PAZs $2-3$ boundary raise the possibility of a hiatus or at least exceptionally slow peat accumulation in that part of the profile. On the basis of the low P. lanceolata values in all spectra (but cereal-type pollen is recorded in most spectra), farming activity is subdued. However, the high contribution initially by Betula and subsequently by Poaceae (both presumably of predominantly local origin) undoubtedly depress the P. lanceolata values.

BHY VI, [> 2600] 2600 BCE-120 CE, i.e. late Neolithic to late Iron Age

The age-depth model for BHY VI is based on a smooth spline curve (smooth factor $=0.5$ ) that takes into account the four available ${ }^{14} \mathrm{C}$ dates and a surface age estimate (peat thickness $160 \mathrm{~cm}$, i.e. $40 \mathrm{~cm}$ added to compensate for peat shrinkage; top regarded as dating to $1950 \mathrm{CE}$; Fig. S2a). The exceptionally old date near the base of the peat $(4080 \pm$ $50 \mathrm{BP})$ does not greatly influence the shape of the curve which is assumed to be correct given that what appears to be the regional pine flush is recorded in BHY VI-2a.

The age-depth curve suggests that peat accumulation started at $2600 \mathrm{BCE}$. Immediately prior to the initiation of peat accumulation, woody vegetation (oak, hazel and especially birch) and heathy grassland (cf. Poaceae and Calluna) were locally common (BHY VI-1; Fig. S6). 
In the basal peat (BHY VI-2a; also in the mineral soil), $B e$ tula values are exceptionally high which suggests that birch continued to be the main contributor to woody vegetation at and near the sampling site as peat began to accumulate. Elevated Pinus values in BHY VI-2a, which span 2600$2270 \mathrm{BCE}$ according to the age-depth model, reflect the regional pine flush. In subzone BHY VI-2b (2270-1810 BCE), there is an increase in Poaceae, Betula begins to decline, and Pinus values have fallen and do not recover. This corresponds closely as regards pollen (also chronology) with zone $2 \mathrm{~b}$ in BHY III and zones 1 and 2 in both BHY IV and V.

Zone BHY VI-3 (1810 BCE-120 CE) reflects a treeless landscape at least in the vicinity of the sampling site. High values for Poaceae are probably attributable to grasses growing on the blanket bog (e.g. M. caerulea and/or Nardus stricta) and grasses on mineral soils in the wider region. In subzone BHY VI-3b, Calluna values are exceptionally high and charcoal (micro- and macro-charcoal) values are also high. These changes are probably ascribable to increased farming activity that included cereal growing (cereal-type pollen is rather well represented). The particularly high values for P. lanceolata and cereal-type at the base of BHY VI3b, i.e. early Iron Age, ca. $400 \mathrm{BCE}$, which are indicative of intensive farming in the vicinity of the site, are noteworthy.

\section{Pollen profiles and spectra from beside the visitor centre} (CF I, CF III and PLM)

Pollen and macrofossil data from short profiles at and beside a stone wall near the visitor centre (CF III and CF I; CF I has also been referred to as CF Ib) are presented in Fig. S7. This figure also includes six pollen spectra (referred to as PLM) relating to soils associated with plough marks that were recorded during excavations conducted on the site of the visitor centre prior to the commencement of construction work (Byrne et al., 2009). Results of calibration of ${ }^{14} \mathrm{C}$ dates (three dates from CF I and a single date from the ploughmark infill), including an age-depth plot for profile CF1, are provided in Fig. S2a. The material was not searched for tephra.

Peat initiation at CF I began at $1000 \mathrm{BCE}$, i.e. in the late Bronze Age. Locally, the landscape was treeless, and grasslands, in which ling played an increasingly important role, dominated (subzone CF I-2a; 950-710 BCE). The lack of trees is attributed to pastoral farming. In subzone CF I-2b, pastoral farming continues, but there is now a considerable arable component that continues to the top of the profile, i.e. into the early medieval period (cereal-type pollen of all size categories are well represented; details are in Molloy and O’Connell, 1995, Fig. 20).

Pollen profile CF III reflects local conditions at, and immediately prior to, wall construction. AP values are low but higher than in $\mathrm{CF}$ I. ${ }^{14} \mathrm{C}$ dates are not available for this short profile, but conditions at a time prior to that represented in CF I-1 are assumed to be reflected here (Pinus values, though low, are higher than in CF I; this supports the idea of a late fourth millennium BCE date). The high fern values (also in the basal samples of CF I) are assumed to result from differential loss of corrosion-susceptible pollen (e.g. Cyperaceae, etc.) and survival of corrosion-resistant pollen and spores and especially fern spores.

Regarding the spectra that relate to the plough-marks (PLM), the pollen representation is broadly comparable to that in CF 1-2. This, and the single ${ }^{14} \mathrm{C}$ date $(2390 \pm 40 \mathrm{BP}$; calibration indicates an $81 \%$ probability that the age lies between 550 and $390 \mathrm{BCE}$ ), suggest that the plough marks relate to the early Iron Age. There are some noteworthy differences within the plough-mark pollen spectra, for instance, the contrasting values for both $P$. lanceolata and cereal-type pollen in samples 1 and 2 versus 3 and 4 . Such differences are not unexpected as the pollen content of soil samples is invariably dominated by pollen of local origin. In samples 5 and 6 (these samples are from the parent soil that contained the plough mark), bog and heath taxa are less well represented, and high values for Poaceae, P. lanceolata and other pastoral pollen indicators suggest that pasture was dominant prior to ploughing and cereal cultivation.

\subsection{Garrynagran}

\subsubsection{Pollen profile GRN I, ca. 5700-1800 BCE, i.e. early mid-Holocene to mid-Bronze Age}

Pollen profile GRN I is from within an extensive bog and hence is expected to reflect, on the one hand, local bog vegetation (cf. bog and heath pollen taxa) and, on the other, vegetation and land use on a wide regional scale (Figs. 5 and 6; Table S2b). Potential complications arise from the distinct possibility, given the high frequency of large timbers (mainly pine, also oak) preserved in the bog, that pollen that would normally be regarded as arising exclusively from vegetation on mineral soils may derive, in part, from mire vegetation. In the latter category are also grasses such as $M$. caerulea (common on blanket bogs) and Phragmites (pollen of these taxa and other grasses are included in Poaceae as is normally done).

In all, there are $11{ }^{14} \mathrm{C}$ dates directly relevant to core GRN I, i.e. nine from slices of peat and two from outer rings of two pine stumps, both present in the peat bank where core GRN I was taken but laterally separated by $\sim 1 \mathrm{~m}$ (Table S1b, c; Fig. S8c). Timber from the outermost rings of the lower and upper pine stumps gave ${ }^{14} \mathrm{C}$ dates $5455 \pm 15 \mathrm{BP}$ and $4110 \pm 20 \mathrm{BP}$, respectively. The age-depth model for the pollen profile is derived from a smooth spline curve (smooth factor $=0.4$ ) fitted to $10{ }^{14} \mathrm{C}$ dates which includes these two pine dates (Fig. S2b). The uppermost peat-derived ${ }^{14} \mathrm{C}$ date, $1170 \pm 30 \mathrm{BP}$ (from depth $10-8 \mathrm{~cm}$; at least $1 \mathrm{~m}$ of peat had been removed by peat cutters), was not used in curve construction as it was regarded as unrealistically young.

The main features of the pollen assemblages are summarised in Table S2b. The lower and middle parts of the 
profile (zones 1-5a) have high AP values (but much reduced values in $3 b$ ) that reflect not only woodland cover on mineral soils but also substantial woodland (mainly pine but also oak) on peat. This is supported by the stomatal pine record (Fig. 5) and also the investigations of pine timbers that are directly associated with GRN I and in the area generally (see Sect. 4.2.2).

The elm decline is a distinct feature (base of $3 \mathrm{a}$ ) and occurs at the expected age (3880 BCE). An unusual aspect (in an Irish context) is the failure to record P. lanceolata (also there is little change in Poaceae) during the elm decline which suggests that opening up of woodland was minimal and that there was little or no farming in the area during the elm decline. Neolithic landnam registers clearly, however, in subzone $3 \mathrm{~b}$. The shape and also the composition of the anthropogenic-indicator pollen component (e.g. Poaceae, $P$. lanceolata, Ranunculus acris-type and Filipendula) indicate a gradual increase in human impact beginning at $3800 \mathrm{BCE}$, relatively high and sustained impact from 3700-3300 BCE, and then a gradual decline that continued to the end of subzone $3 \mathrm{~b}$ (3240 BCE) and into zone 4. Interesting also are the changes in mire conditions during subzone 3b. Sphagnum macrofossils (mainly leaves) are important for the first time (Sphagnum spores and capsules were well represented before this, but no leaves were recorded; Figs. 5 and 6). Initially, the leaves are mainly of $S$. sect. Acutifolia and, later, S. palustre, and, at the base of zone 4, S. austinii (i.e. S. imbricatum) is recorded, but this species does not become dominant until $2750 \mathrm{BCE}$ (base of zone 5). A trend towards lower ash values (higher LOI) that begins at the base of zone 3 also suggests a change in mire hydrology that probably involved a shift from rheotrophic to ombrotrophic conditions.

The regional pine flush, on the basis of the pollen record, is of ca. 130 years duration (subzone 5a). The pine timber (P2; Fig. S8c) associated with this feature had a lifespan of ca. 120 years and, based on the ${ }^{14} \mathrm{C}$ date from the outer rings of the stump (Fig. 7), died shortly before 2600 BCE. Interestingly, most of the stumps in the vicinity of the coring site were stratigraphically related to the lower stump (P1) so that pine stump P2, which was almost $1 \mathrm{~m}$ higher in the peat, seemed to be an isolated specimen. However, other pines were probably growing nearby on peat, at about the same time as P2, and were presumably contributing to the pine flush (see Sect. 4.2.2).

The start of the pine flush coincides with the beginning of the continuous dominance of $S$. austinii and also a record for Racomitrium moss (Fig. 6). Whether or not this shift preceded, coincided with, and was subsequent to, the local presence of pine trees on the bog surface is difficult to say. The stratigraphy suggests that the stump may have predated these changes.

Bearing in mind the more or less continuous pine-stomata record and the results of ${ }^{14} \mathrm{C}$ and dendrochronological investigations of pine timbers from elsewhere on the bog (see Sects. 4.2.2 and 5.1; also Jennings, 1997), it can be concluded with confidence that pine grew in at least some places on the mire over the entire period, apart from the youngest interval, i.e. apart from subzone 5b and zone 6 (from 2600 BCE onwards; Figs. 5 and 6).

\subsubsection{Radiocarbon dating of bog pine in north Mayo and dendrochronological investigations at Garrynagran}

The results of ${ }^{14} \mathrm{C}$ dating of pine-wood samples from northwest, west and central Co. Mayo are shown graphically in Figs. 7 and 8, and details are provided in Table S1b. In Fig. 7, probability curves from calibration of $68{ }^{14} \mathrm{C}$ dates (these including three replicate dates from Belderrig) of pine timbers are plotted. Provenance and stratigraphic context of the timbers involved are also indicated. In Fig. 8, histograms are used to show age frequencies (200-year bins) for all pine dates (Fig. 8a; in the case of the replicate dates from Belderrig, the UBA rather than UCD dates are included). The dates are grouped according to geographical areas, i.e. Céide Fields together with nearby Aghoo and Annagh More and Annagh Beg (referred to as Annagh Tds), Belderrig, Garrynagran and Carrowkennedy and Inishbofin, and Shanvallycahill, i.e. a cutover peatland on the south-west shore of Lough Mask (Fig. 8b-f). The thickness of peat beneath the timbers is schematically indicated (details in Table S1b).

The ${ }^{14} \mathrm{C}$ dates are decidedly concentrated in the interval 3400-2400 BCE, with the greatest concentration in the interval 3200-2600 BCE which can be regarded as the period characterised by widespread growth of pine on bog and peaty surfaces, i.e. the regional pine flush. The widest span of dates is recorded from the Erris region (ca. 6400-1350 BCE) but here too most of the dates are concentrated in the interval 3400-2200 BCE.

As regards thickness of peat beneath the timbers, not surprisingly many (20) are associated with a thin layer of peat ( $\leq 50 \mathrm{~cm}$; these statistics include the 47 pine ${ }^{14} \mathrm{C}$ dates discussed in Caulfield et al., 1998; information was not provided for C52). Relatively few pine stumps (9) rest on mineral ground which again is not too surprising as peat growth is expected to have commenced during the lifetime of the tree or shortly after death; otherwise the chances of preservation would have been small. Rather surprisingly, however, several timbers were recorded on substantial thicknesses of peat $(51-100 \mathrm{~cm}, 10 ;>100 \mathrm{~cm}, 13)$ which may have taken several centuries to accumulate. This suggests that blanket bog was already present as Neolithic culture spread though it remains unclear how widespread blanket bog was (extensive areas without megaliths, however, may be indicative of widespread presence of bog in parts of the region at the time of expansion of Neolithic peoples) and the degree of landscape openness, particularly at a local level, due to presence of bog as farming commenced (evidence supporting landscape openness at a local level is lacking). As emphasised by Caulfield et al. (1998), the two pine stumps recorded on 

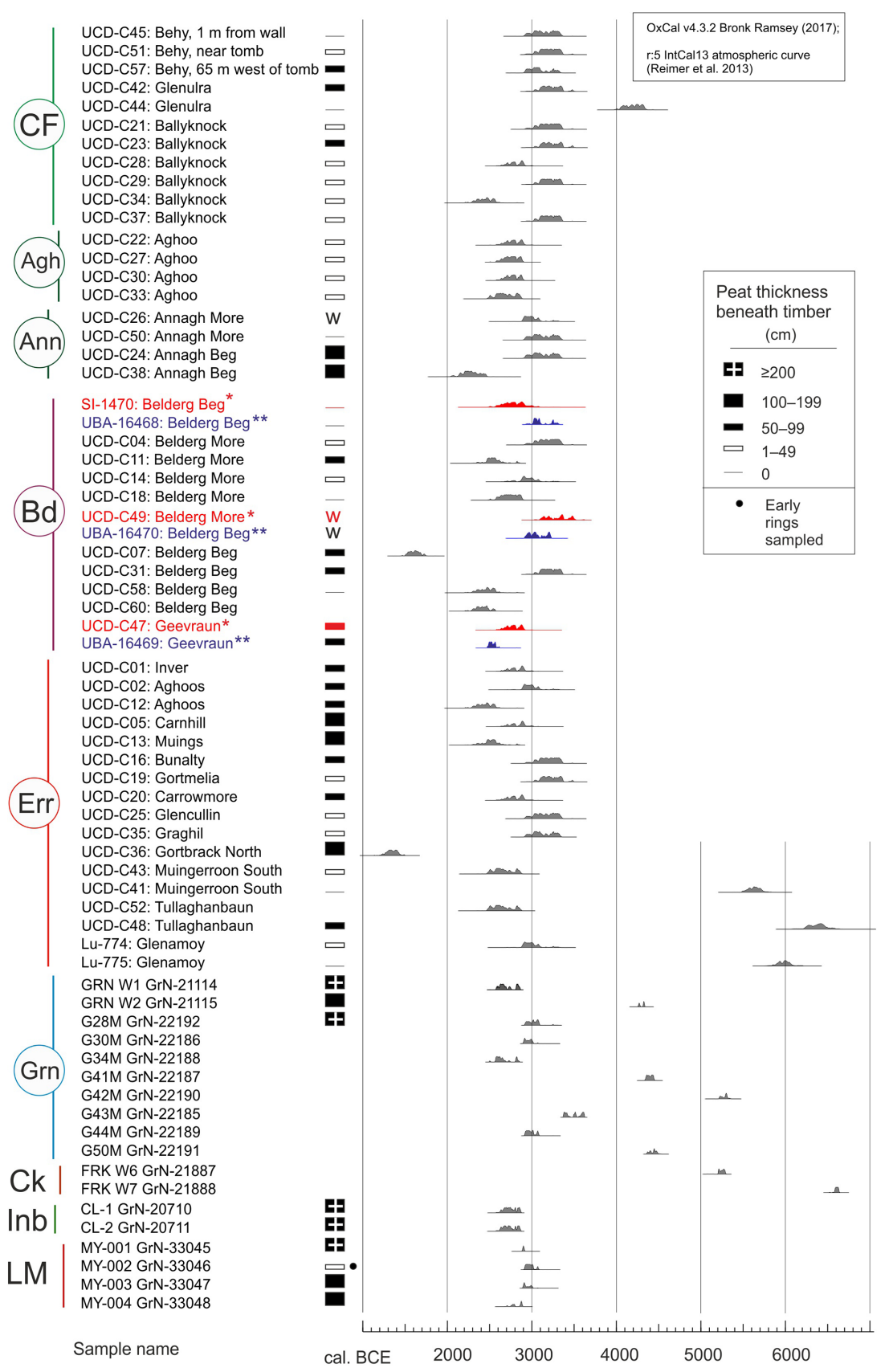

UCD.C31: Belderg Beg

UCD-C60: Belderg Beg

UCD-C47: Geevraun*

UCD-C01: Inver

UCD-C02: Aghoos

UCD-C13: Muings

CD-C20: Carrowmore

UCD-C25: Gronculli

CD-C35: Graghil

UCD-C43: Muingerroon South

UCD-C41: Muingerroon South

Tughanbaun

RN W1 GrN-21114

2 GrN-21115

G41M GrN-22187

MY-001 GrN-33045

MY-002 GrN-33046

Sample name

Figure 7. Results of calibration of ${ }^{14} \mathrm{C}$ dates from bog-pine wood from Co. Mayo. Sample names include the ${ }^{14} \mathrm{C}$ laboratory number and, in some instances, the label given by the laboratory that took and submitted the sample for dating is given. In the case of samples for which University College Dublin was responsible (UCD in the number indicates dating by its radiocarbon laboratory), the townland name is given. Note that Lu-774 and Lu-775 relate to Lund University. The curves show the calibrated ages (probability distributions, 95.4\% and 99.7\%) of $68{ }^{14} \mathrm{C}$ dates that relate to the following areas: ${ }^{1} \mathrm{CF}$, Céide Fields; ${ }^{1}$ Agh, Aghoo (5 km south-east of visitor centre (VC), CF); ${ }^{1}$ Ann, Annagh More and Annagh Beg (10 km south-east of VC, CF); ${ }^{2} \mathrm{Bd}$, Belderrig $(6 \mathrm{~km}$ west of CV, CF $) ;{ }^{3}$ Err, Erris region; ${ }^{4} \mathrm{Grn}$, Garrynagran $(16 \mathrm{~km}$ south of Céide Fields), ${ }^{4}$ Ck, Carrowkennedy, W. Mayo; ${ }^{5}$ Inb, Inishbofin (Cloonamore); and ${ }^{6}$ LM, Shanvallycahill, L. Mask. Replicate ${ }^{14} \mathrm{C}$ dates are presented from three timbers that relate to Belderrig, i.e. original ${ }^{14} \mathrm{C}$ dates and later obtained $\mathrm{AMS}{ }^{14} \mathrm{C}$ dates (indicated by $*$ and **, respectively). Calibration results for both sets of dates are plotted; the original dates, which have larger standard deviations, are not included in the compilation shown in Fig. 13. Peat thickness beneath the specimens is indicated schematically, where available. Primary data sources are as follows: ${ }^{1}$ Caulfield et al. (1998); ${ }^{2}$ Caulfield et al. (1998, 2011a); ${ }^{3}$ Caulfield et al. (1998); Håkannson (1974); ${ }^{4}$ Jennings (1997); ${ }^{5}$ Ní Ghráinne (1993); O’Connell and Ní Ghráinne (1994); and ${ }^{6}$ O’Connell (unpubl.). Most of the dates derive from outer tree rings, except MY-002 GrN-33046 (marked by a closed circle) that derives from inner rings. Details of the part of the timbers used for dating by Caulfield et al. (1998) and Håkannson (1974) are mostly not available; in a few instances it is indicated that the outer rings were dated, and so it is assumed that this is generally the case. 


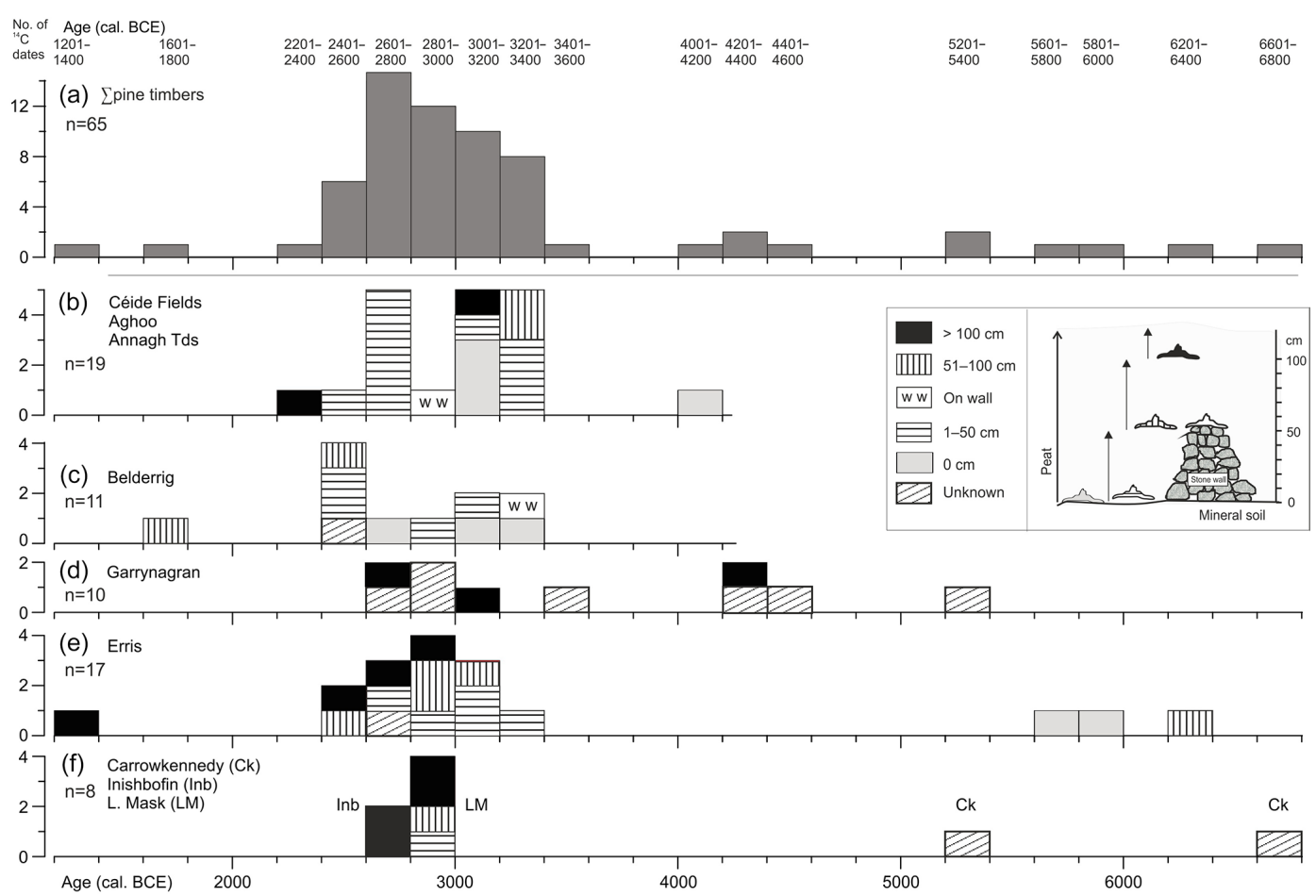

Figure 8. Histograms showing age-frequency distribution (calibrated medium ages derived from OxCal) of pine stumps from Co. Mayo (for sources see legend to Fig. 12). Fill patterns are used to show the depth of peat on which the ${ }^{14} \mathrm{C}$-dated pine stumps occurred; a schematic representation of the relationships of the pine stumps to the mineral soil or peat and stone walls is provided in the inset.

a stone wall (see Discussion; presumably drainage resulting from the stone wall created a locally favourable environment for these trees to germinate, establish and grow) are important indicators of age of wall construction. The walls in question date to ca. $3000 \mathrm{BCE}$ at the latest, and, most likely, are a couple of centuries older if allowance is made for the inherent age of the tree (outer rings dated). So, with confidence, construction of these walls can be justifiably imputed to the Neolithic; i.e. they are much older than the late Bronze Age dating argued for by Whitefield (2017).

The results of the dendrochronological investigations at Garrynagran are presented in Fig. 9. The age span of individual pine and oak timbers that have been dendrochronologically dated (the pine chronologies are floating; the oak chronology is fixed) are plotted as well as ${ }^{14} \mathrm{C}$ dates from pine timbers including the date used to "fix" the two floating pine chronologies, P2M and P1M.

Centres of the five trees included in P1M were preserved, but sapwood was not present in any sample. Matching of G49M with G50M gave a $t$ value of 12.02 (this was the maximum $t$ value for the pine timbers). There is the possibility that the samples relate to the same tree (the samples came from stumps removed from the surrounding bog and stacked) but it is also possible that the trees grew in close proximity which could explain the high correlation (Fritts, 1976). The G40M ring series is only 66 years in length, and hence $t$ val- ues are low. However, visual comparison of the plotted ring widths suggested that it matched well, and so G40M has been included in master chronology P1M.

The floating chronologies P1M and P2M, each of which was fixed on the basis of a calibrated ${ }^{14} \mathrm{C}$ date from a selected timber (see Methods; Fig. 9c), have a duration of 438 and 183 years, and span the intervals ca. 3135-2700 and 45304350 BCE, respectively (Jennings, 1997). Pine timbers G43 and $\mathrm{G} 42$ yielded ring patterns that could not be matched, and ${ }^{14} \mathrm{C}$ dating confirmed that these were older than $\mathrm{P} 1 \mathrm{M}$ and P2M, respectively. Pine timbers $\mathrm{P} 2$ and $\mathrm{P} 1$, that were ${ }^{14} \mathrm{C}$ dated but not dendrochronologically investigated, are interesting in that the former fits in well with P1M (pine flush), while P1 relates to the younger part of P2M and could potentially extend that chronology forward by some years (Fig. 9c). The eight pine trees that constitute P1M were all alive at ca. 2950 BCE and possibly also pine P2 that was not dendrochronologically investigated. The three oak trees also began life at about this time (Fig. 9b). Thus an interval centred on $3000 \mathrm{BCE}$, and including a century or so on either side of that date, is highly significant as regards the final phase of tree growth on peat surfaces at Garrynagran. 


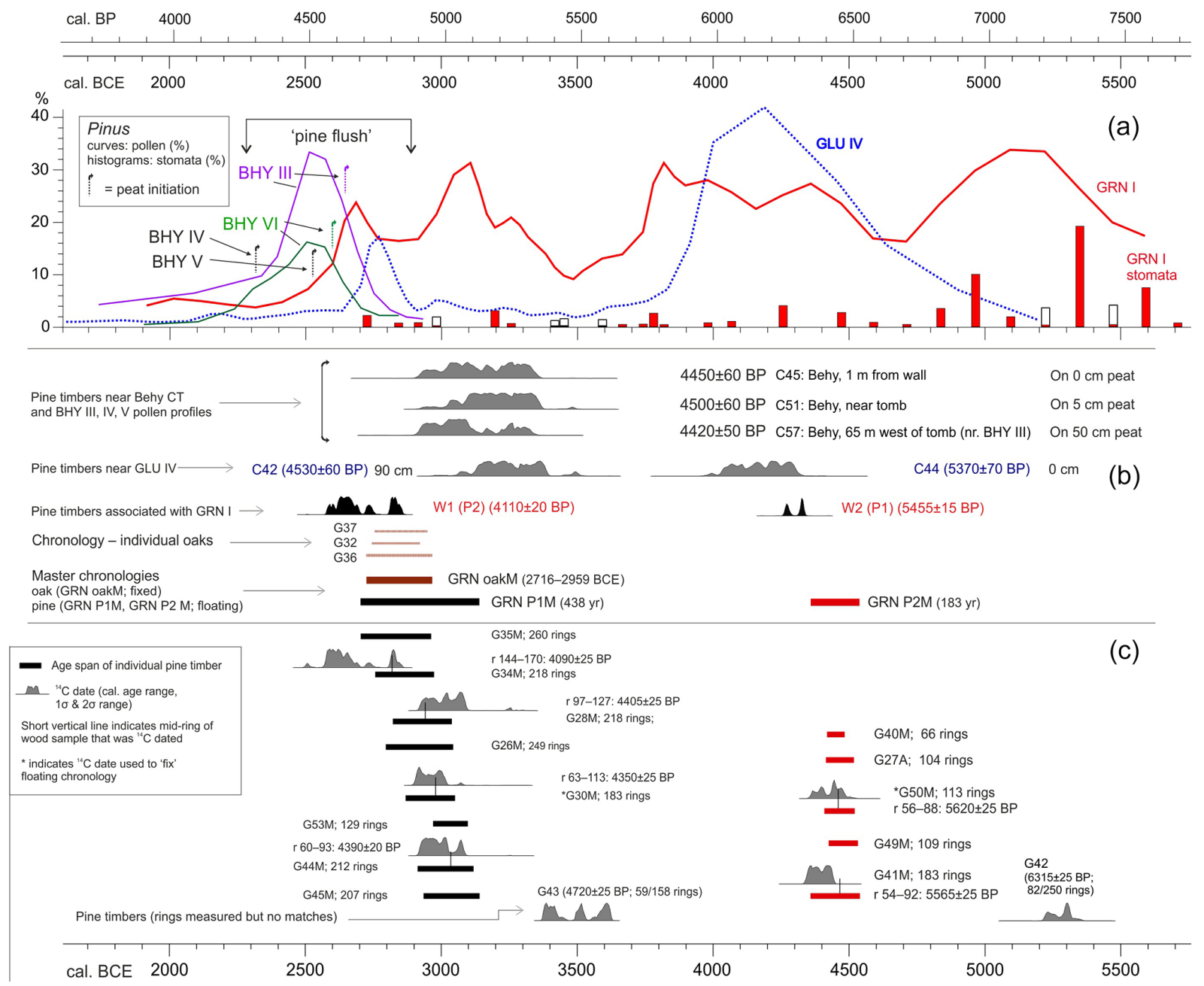

Figure 9. Overview of data relating to pine and other developments in north Mayo in the interval 5700-1700 BCE plotted on a calendarcalibrated timescale (BCE and cal. BP; both calibrated]. (a) Pinus percentage data from pollen profiles that show a pine flush. The curves are weighted averages of three values; the central value is accorded double weighting. Data are plotted as follows (PAZs are specified): GLU IV-3 to -8 , BHY III- 1 to $-2 b$ and BHY VI-1 to $-2 b)$; the beginnings and ends of curves where values are low $(<\sim 1 \%)$ are not shown; for GRN I the complete profile is plotted. Peat initiation dates are indicated for BHY profiles; that the age may be underestimated is suggested by an arrowhead pointing towards older ages (see text). Pine stomatal data (\%; silhouette indicates $\times 10$ exaggeration) for GRN I are shown. (b) Master chronologies from Garrynagran, i.e. two floating pine chronologies and one fixed oak chronology (three timbers). Time intervals represented by individual oak timbers, G32, G36 and G37, are indicated. (c) Chronologies for individual pine timbers from Garrynagran (dendrochronological data and results of ${ }^{14} \mathrm{C}$ dating; $r$ is ring nos.) that are included in the floating pine chronologies GRN P1M and GRN P2M. Probability curves for calibrated dates from pines G42 and G43 (dendrochronologically investigated but without matches) and pines W1 and W2 (also referred to as P2 and P1, respectively) from beside pollen profile GRN I are also shown.

\section{Discussion}

\subsection{Chronology, pine dynamics and blanket-peat formation}

The chronologies attached to the various palaeoecological components of the investigations reported on are first considered. Reliance is placed on radiocarbon dating as the best independent indicator of age. We focus on ${ }^{14} \mathrm{C}$ dates from peat cores that have been pollen analytically investigated at Céide Fields and Garrynagran and also on ${ }^{14} \mathrm{C}$ dates obtained from pine timbers (stumps and trunks) in the wider region. The latter are particularly useful for a variety of reasons including the high integrity of the samples, and, in the case of several dates, the errors attached to the ${ }^{14} \mathrm{C}$ dates are small. The dates published by Caulfield et al. (1998) derive from a geographical area that extends $36 \mathrm{~km}$ across north Mayo from close to Killala Bay in the east to Broadhaven Bay and Blacksod Bay in the west. The importance of these dates derive, in the first instance, from the information they provide for the presence and age of peat (mainly but not exclusively 
blanket bog) at a regional scale and hence, indirectly, the age of pre-bog stone walls (in general stone walls in the region are seldom found on peat but are invariably occluded by peat; see Introduction). Two of these pine-timber dates derive from stumps situated on stone walls and so provide terminus ante quem dates for stone-wall construction at the particular sites (UBA-16470, 4580 $\pm 60 \mathrm{BP}$, from Belderg More, $1.3 \mathrm{~km} \mathrm{NE}$ of Belderg; C26, 4350 $\pm 60 \mathrm{BP}$ from Annagh More, $6.5 \mathrm{~km}$ SE of VC, Céide Fields; Fig. 7).

The ${ }^{14} \mathrm{C}$ dates from pine timbers in Garrynagran serve to validate and chronologically fix floating pine chronologies constructed using dendrochronological methods from this extensive mire (Figs. 2a and 9). The dendrochronological investigations show that pine trees were most frequent on peat during a narrow window of about two centuries centred on $4450 \mathrm{BCE}$ and later in a wider window that extended from ca. 3150-2700 BP (Fig. 10). In the latter period the three substantial oaks that have been dendrochronologically dated also grew on peat. The pollen data, including a pine stomatal record, point to a more or less continuous record for pine growing on peat at Garrynagran beginning at ca. $5700 \mathrm{BCE}$ (when the pollen record begins) and continuing for ca. 3100 years, i.e. to the top of PAZ GRN I-5a. After this, pine was still present (though much less frequent) in the landscape but seems to have generally failed to establish itself on bog surfaces, the most likely reason for which being not lack of seed, but increased surface wetness that inhibited germination and establishment.

The main pollen profile from Céide Fields, i.e. profile GLU IV, indicates sustained and intensive human impact arising from farming that was mainly but not exclusively pastoral (Molloy and O'Connell, 1995) over the period 38003160 BCE (subzones 5b and 5c; this is regarded as Neolithic landnam), with farming possibly commencing as early as 3950 BCE (5a; the base of this subzone corresponds with the elm decline which is not an important feature as elm was unimportant; pine, hazel, birch and oak were the main woodland trees; Fig. 3). Other Irish pollen profiles with a pronounced Neolithic landnam include Littleton Bog (Mitchell, 1965), Fallahogy (Smith and Willis, 1962), Lough Sheeauns (Molloy and O'Connell, 1991), Templevanny Lough (Stolze et al., 2013) and Lough Muckno (Chique et al., 2017). Compared with these, landnam as recorded in GLU IV is much more pronounced, and so we conclude that this was a particularly intensive farming phase. If, as is not disputed, the regular stone-wall field system was constructed in the context of farming, and given the demonstrated antiquity of the stone-wall system, it appears reasonable to equate the landnam phase with the laying out and use of the field system. It is also reasonable to assume that the main construction phase is reflected in subzone $5 \mathrm{~b}$ when trees were absent or extremely scarce, and so the landscape was open which facilitated the construction of the highly regular, stone-wall enclosure system. It is envisaged that active land use continued, though somewhat abated, into subzone $5 \mathrm{c}$. We envisage the main stone-wall construction phase lasting some decades. The regularity of the system points to a well-coordinated plan that, presumably, was executed relatively rapidly, possibly within a human generation or two.

Pollen profiles GLU IV and GRN I each has a chronology that is well constrained by ${ }^{14} \mathrm{C}$ dates. However, the same level of certainty does not apply in the case of the chronologies attached to the shorter profiles from Céide Fields. In addition to the inherent difficulties of dating basal peats, the number of ${ }^{14} \mathrm{C}$ dates available is small, and, furthermore, these are mainly bulk peat dates (dating a specific component such as Sphagnum leaves is much more satisfactory; also basal peat in blanket-bog contexts normally accumulates slowly so that many decades may be represented in a $1 \mathrm{~cm}$ thick sample (cf. dates for pine and underlying peat at Geevraun, i.e. $4026 \pm 45$ BP (UBA-16469) and $5710 \pm 90$ BP (C46), respectively; Caulfield et al., 1998, 2011a)). In view of the likelihood of root penetration and downward movement of humic acid and fine particulate matter, bulk ${ }^{14} \mathrm{C}$ dates from basal peat contexts may well underestimate true age.

Pinus percentage pollen curves are bought together and plotted in a summary diagram with other relevant information in Fig. 11 to facilitate inter-site comparison and evaluation of ${ }^{14} \mathrm{C}$-derived ages. Profile GLU IV, from Glenulra basin, is first considered. A large peak in Pinus values near the base of the profile (PAZ GLU IV-4 in Fig. 3; the lower pollen spectra of GLU IV are not included in Fig. 11 because of space limitations) is regarded as reflecting pine growing in the small Glenulra basin mire and also on nearby mineral soils. Pine timber C44, from the edge of Glenulra basin and on mineral ground and dated to $5370 \pm 70 \mathrm{BP}$ (Caulfield et al., 1998), falls within this time window. The later peak in Pinus, i.e. the pine flush, on the other hand, is in a wellage-constrained part of profile GLU IV (Fig. 11). It spans the interval 2820-2720 BCE (PAZ 6b) and thus potentially lies within the younger part of the pine flush time window. Pine timber C42, also from the edge of Glenulra basin but on $90 \mathrm{~cm}$ of peat, is however considerably older $(4530 \pm 60 \mathrm{BP})$ than the pine flush (Fig. 11). It should be borne in mind, however, that single pine trees or indeed several pine trees, even if growing near a sampling site, will not necessarily be reflected in a Pinus pollen curve (cf. Smith and Goddard, 1991).

In pollen profile GRN I, Pinus values are high $(21.5 \pm$ $7.6 \% ; n=44)$ until after the pine flush. The ${ }^{14} \mathrm{C}$ date $6315 \pm$ $25 \mathrm{BP}$ (G42, rings 66-98) and the Pinus stomatal record support the idea that pine was common on this mire from at least $5700 \mathrm{BCE}$, i.e. when the pollen record commences. This is supported by the ${ }^{14} \mathrm{C}$ dates from pine timbers and also the floating pine chronology GRN P2M (spans 183 years, i.e. ca. $4530-4350$ BCE). The final elevated values for Pinus in profile GRN I (GRN I-5a; $23 \pm 3 \%$, i.e. the regional pine flush) span the interval 2750-2620 BCE (Fig. 11). There is also an interval prior to this, centred on $3100 \mathrm{BCE}$, during which there was a substantial pine population on bog (Fig. 10). The small pine stump from beside pollen profile GRN I that 


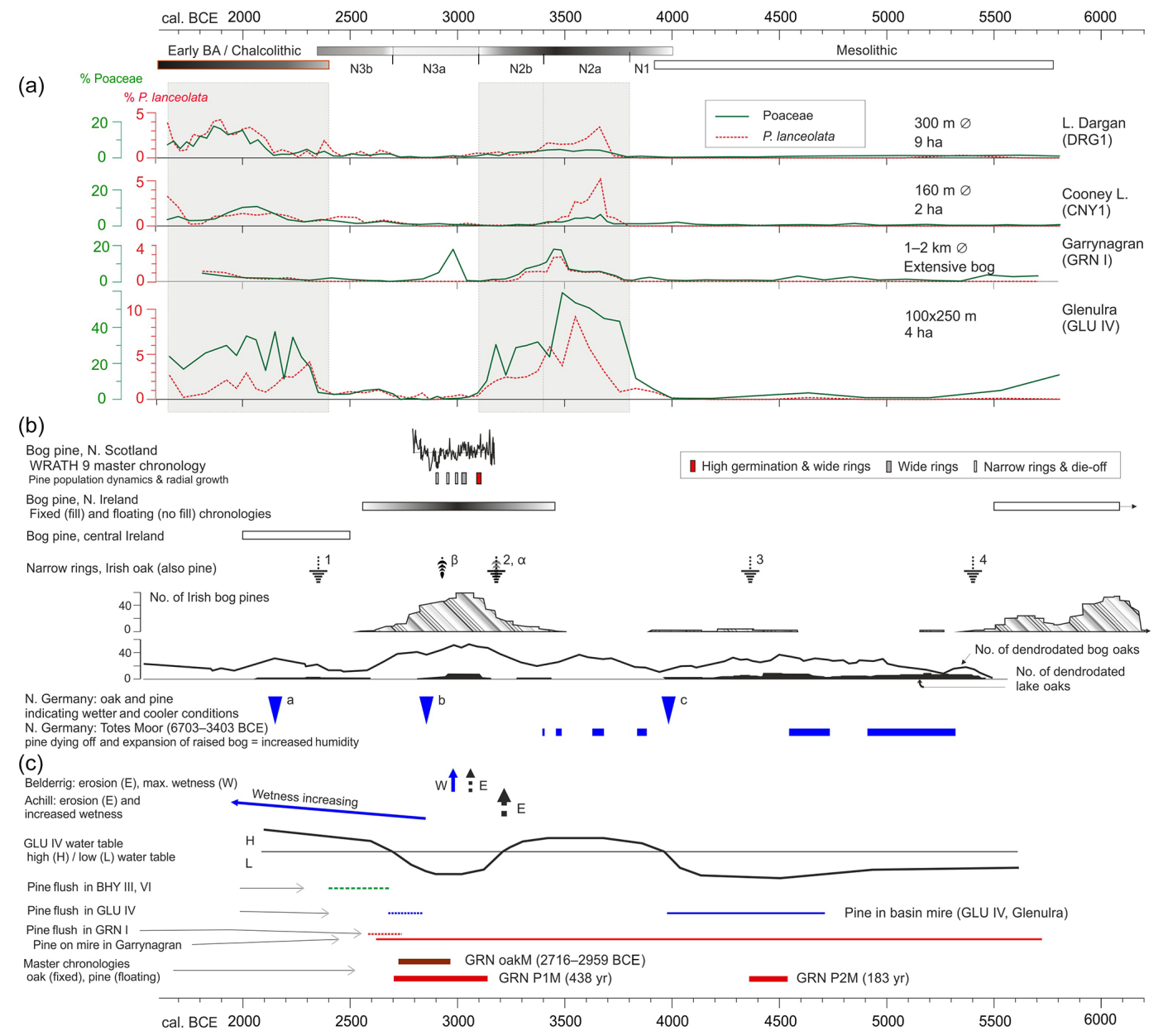

Figure 10. Overview of results from dendrochronology, ${ }^{14} \mathrm{C}$ dating and pollen analysis relating to Céide Fields and Garrynagran plotted against a BCE (calibrated) timescale. Sources of data, other than data presented in this paper, are indicated. (a) Main cultural phases. The Neolithic is divided into phases based on levels of human impact: N1 (human impact low), N2a (highest impact, intensive landnam), N2b (declining impact), N3a (pronounced lull) and N3b (impact begins again). Pollen percentage curves for $P$. lanceolata and Poaceae for profiles DRG1 (L. Dargan; Ghilardi and O'Connell, 2013), CNY1 (Cooney L.; O'Connell et al., 2014) and Glenulra (GLU IV). Chronology is as in the publications cited. The $y$-axis scale for P. lanceolata is $\times 5$ with respect to Poaceae. Sizes of the basins (diameter and extent) are indicated. Shading is used to suggest levels of farming activity. (b) Bog pine, northern Scotland. The fixed master chronology WRATH 9 is shown; this matches the Irish oak master chronology. Pine population dynamics (germination and die-off) and main radial growth patterns are indicated (Moir et al., 2011). Bog pine, northern Ireland (Pilcher et al., 1995). Fixed chronology (filled rectangle; the denser the shading, the higher the pine specimen frequency) and an older floating chronology (open rectangle; age span $5500-6300 \mathrm{BCE}$ (based on ${ }^{14} \mathrm{C}$ dates); oldest part is beyond the scale and is not shown). A short chronology from Fallahogy Bog that starts shortly after 7000 BCE is also not shown because of scale constraints. Bog pine, central Ireland. Floating chronology (fixed by ${ }^{14} \mathrm{C}$ dates), from raised bogs (McNally and Doyle, 1984). Narrow-ring events recorded in Irish oak (also pine). 1 is 2345 BCE; 2 is 3195 BCE; 3 is 4375 BCE; 4 is 5400 BCE (Baillie, 1994 , 1999). Reductions in pine ring widths (from Pilcher et al., 1995) coincide with event 2 (marked $\alpha$ ) and occur also in 2911 BCE (marked $\beta$; see Baillie, 1999). Nos. of Irish bog pines and nos. of dendrodated bog oaks and lake oaks (from below present-day lake levels; after Turney et al., 2006), indicating bog-surface dryness and low lake levels. Northern Germany: wet phases inferred from bog-pine records from N. Germany. Symbol a is 2150 BCE, b is 2850 BCE, c is 3990 BCE (a and b are referred to as long-lasting "severe wet phases"; c as the beginning of die-off of bog pine, most trees dead within 10 years, oak ring widths also depressed; Eckstein et al., 2011). Period "b" also marks an extremely wet phase at Campemoor, Dümmer See, when pine-trackway construction took place using pine that was growing locally on the bog (Leuschner et al., 2007). Northern Germany: Totes Moor. Pine dying-off and expansion of raised bog phases, most likely due to wetter conditions (Achterberg et al., 2018). The dendrochronologically dated pine record relates to 6703-3403 BCE. (c) Belderrig: soil erosion and maximum wetness at the main archaeological site (Verrill and Tipping, 2010a). Achill: major soil-erosion event at ca. $3200 \mathrm{BCE}$ and increased wetness beginning at ca. 2850 BCE (Caseldine et al., 2005). GLU IV water table (schematic) based mainly on pollen data (cf. Molloy and O'Connell, 1995). Pine flush refers to elevated Pinus percentage values in the particular pollen profiles. Pine growing on mire is based mainly on pollen data, including pine stomatal data, and also ${ }^{14} \mathrm{C}$-dated pine timbers in the case of profile GRN I. Note: ${ }^{14} \mathrm{C}$-based age-depth models probably underestimate the age of the pine flush in profiles BHY III and IV (see Discussion). Dendrochronologies from Garrynagran (oak is fixed; two floating pine chronologies are fixed by ${ }^{14} \mathrm{C}$ dating). 


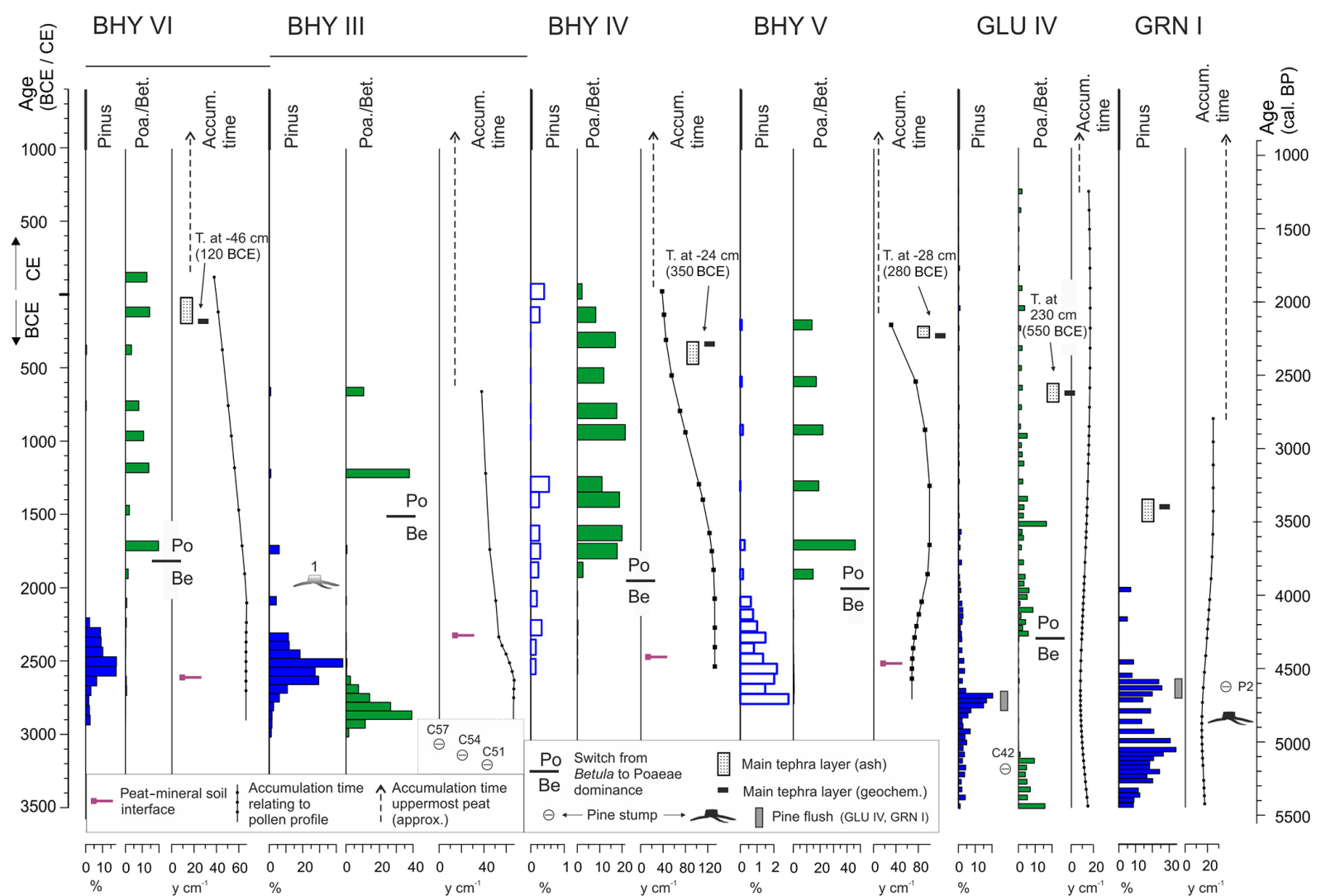

Figure 11. Overview of chronological markers associated with pollen profiles, BHY series, GLU IV and GRN I. The following are shown (plotted to a calibrated timescale; chronology based on age-depth model for the respective profile): Pinus pollen percentage values (non-filled histograms used where $x$ scale is $\times 10$; pine flush is marked only in GLU IV and GRN I), percentage Poaceae/Betula ratios (GRN I lacked a clear pattern and so is not plotted), and curves for deposit accumulation time $\left(\mathrm{y} \mathrm{cm}^{-1}\right)$. The upper part (dashed line) indicates average accumulation time; it should be regarded as broadly indicative only, especially in GRN I. Also shown: position of mineral soil-basal peat interface for BHY profiles, tephra layers as detected by ashing and also tephra that was geochemically characterised (main concentrations indicated), and pine stumps. A line within a circle indicates the median calibrated age of a ${ }^{14} \mathrm{C}$-dated stump. Stumps C51, C54 and C57 are from the vicinity of pollen profiles BHY III-IV; C42 is from the vicinity of GLU IV; P2 is directly associated with pollen profile GRN I. Diagrammatic representations of pine stumps (1 and P2; 1 was on 10-15 cm of peat, $30 \mathrm{~cm}$ distant from BHY III; P2 is directly associated with GRN I; its ${ }^{14} \mathrm{C}$ date is positioned with respect to the timescale) are indicated with respect to their stratigraphic position relative to the pollen data rather than the timescale.

gave the date $4110 \pm 25 \mathrm{BP}$ (ca. $2660 \mathrm{BCE}$ ) may have contributed, at least partly, to these high values. The floating pine chronology GRN P1M (438 years) spans the interval ca. 3135-2700 BCE; i.e. it more or less fits into the interval defined by these two Pinus peaks. After the pine flush, the low Pinus values in GRN I $(5 \pm 2.4 \% ; n=9)$ suggest that pine persisted, probably mainly on mineral soils, until at least 1800 BCE when the pollen profile GRN I ends. Despite the contrasting geomorphological setting at Glenulra and Garrynagran (small deep basin vs. an extensive mire covering gently undulating terrain), there is good agreement regarding the pine records and especially the pine flush phenomenon.

As regards the short BHY peat profiles from Céide Fields, only two of the four profiles show a pine flush (BHY III and VI). Given that this is an event of wide regional significance (recorded also by Moore (1979) and Bourke (1972); see Fig. S1), it is assumed that at BHY IV and V peat had not yet begun to accumulate locally, i.e. near Behy court tomb, and so these profiles fail to capture this event. The age-depth models for profiles BHY III and VI (based on ${ }^{14} \mathrm{C}$ dates and developed independently) indicate that the pine flush is centred on or occurred somewhat earlier than $2500 \mathrm{BCE}$, i.e. a century or two later than the same event in profiles GLU IV and GRN I. While such a late date is possible, it is unlikely especially given that the ${ }^{14} \mathrm{C}$ dates from pine timbers indicate that more than half the ${ }^{14} \mathrm{C}$-dated pine trees from Céide Fields and its environs (Fig. 7) were probably dead by 3000 BCE (it is assumed that the samples dated by Caulfield et al. (1998) derive mainly from outer tree rings). It is therefore best to consider the pine flushes in BHY III and VI as being of similar age to those in GLU IV and GRN I (2820 2720 BCE and 2750-2620 BCE, respectively), which have 
tightly constrained chronologies. The pine timber ${ }^{14} \mathrm{C}$ dates from close to BHY III (three in all; Figs. 1 and 9) also support this view. Hence we conclude that the age-depth models underestimate the age of the basal peat in BHY III and VI. In other words, peat more than likely began to accumulate at these sites no later than ca. $2750 \mathrm{BCE}$, i.e. in the late Neolithic.

According to the age-depth model, peat initiation at BHY $\mathrm{V}$ begins at ca. $2300 \mathrm{BCE}$ (Fig. 11). Whether this underestimates when peat begins to accumulate at this site is not easily evaluated. Pinus is recorded in the basal spectra at $1 \%-2 \%$; i.e. pine is probably still present locally, but clearly the pine flush is not captured. It is probably best to continue to regard $2300 \mathrm{BCE}$ as the best available indication of age of peat initiation at this location though in all likelihood it is a minimum age.

Another important feature of the BHY profiles (also GLU IV but not as pronounced) is the dominance of Betula during the initial stages of peat initiation and the subsequent sharp rise to dominance of Poaceae at the expense of $\mathrm{Be}$ tula (see the relevant pollen diagrams and Fig. 11 where Poaceae/Betula ratios are presented). Betula and Poaceae pollen are probably arising from birch and grasses (e.g. $M$. caerulea), respectively, present at or close to the sampling sites mainly on peaty soils. That birch could flourish suggests low levels of farming activity, i.e. few grazers. Interestingly, birch charcoal dominates several of the charcoal assemblages from late Neolithic and early Bronze Age contexts in the excavations carried out at the Céide Fields Visitor Centre prior to its construction (O’Donnell, 2011).

It is unclear what triggers the switch from Betula to Poaceae dominance in the Bronze Age (prior to $1500 \mathrm{BCE}$ ). The apparent lack of synchroneity would appear to exclude climate as the main factor, while increases in P. lanceolata point to increasing human impact. Particularly high values for P. lanceolata (up to $12.1 \%$ ) are recorded in profile BHY IV in the late Bronze Age (Fig. S4). This suggests that human activity and non-peaty soils persisted in the vicinity of Behy court tomb until well into the Bronze Age and possibly the early Iron Age.

The pollen profile CF I is an outlier as regards pollen and also age (Figs. S7 and S2a, respectively). Here peat began to accumulate in the late Bronze Age (ca. 1000 BCE) in the context of an open, more or less treeless, and grass-dominated environment. The plough (ard) marks discovered nearby (see Introduction) are probably older but not so old as not to be ascribable to the same cultural period, i.e. the late Bronze Age. Thus they are probably broadly similar in age to the ard marks that underlie the cultivation ridges at Belderrig (see Introduction). If the chronology as proposed is correct, they would appear to be somewhat older than the extensive, broad and well-defined cultivation ridges recorded beneath blanket peat at Carrownaglogh, $37 \mathrm{~km}$ to the south-east of Céide Fields (O'Connell, 1986).

\subsection{Early prehistoric farming - an overview with particular reference to mid-western Ireland}

After the inception of farming in the mid-Holocene, human impact becomes the main and often dominant factor influencing environmental change. Human impact, however, is not the sole factor, rather it is that which modifies, and often fundamentally changes, the direction of change induced by other long-term influences including pedogenesis, plant competition and succession, and climate change. Deciphering which specific factors are operating at particular times and places is never easy partly because we often do not have the detailed evidence to identify and quantify the changes or to disentangle how a complex web of changes is being driven (cf. Arponen et al., 2019a, b; Riede, 2019).

In the case of north Mayo we are fortunate in now having a rather comprehensive dataset that allows us to make some important deductions. This dataset is summarised in Fig. 10. Poaceae and $P$. lanceolata curves from the long pollen profiles GLU IV and GRN I, as well as pollen profiles DRG1 (Lough Dargan) and CNY1 (Cooney Lough) from nearby Co. Sligo (Ghilardi and O'Connell, 2013; O'Connell et al., 2014), show well-defined and closely synchronised patterns of human impact in a relatively small area. Substantial impact (landnam) characterises the early Neolithic (phase N2a, 3800-3400 BCE; Fig. 10). The strongest impact registers in GLU IV which is not surprising if our hypothesis that this is the period of stone-wall construction (and, by implication, more or less complete woodland clearance) at Céide Fields is correct. In Neolithic phase N2b (3400-3100 BCE) farming has declined. Interestingly, however, there is still substantial farming in north Mayo and especially at Céide Fields (GLU IV) where, presumably, the field system continued in use in the context of predominantly pastoral farming, i.e. farming based primarily on animal husbandry that presumably involved mainly cattle rearing which appears to have been allimportant in the Irish Neolithic (Woodman, 2016; also McCormick (2007) who stresses the dearth of securely dated Neolithic bone material in Ireland).

The later Neolithic phases N3a and N3b (3100-2700 BCE and 2700-2350 BCE) are characterised by a lack of evidence for farming and low-level farming activity, respectively. This corresponds to the gap in activity in the Irish Neolithic, highlighted by O'Connell and Molloy (2001) on the basis of pollen evidence and subsequently complemented by evidence derived from macrofossils (especially cereals) and other tightly age-constrained data derived from archaeological excavations (cf. Cooney et al., 2011; McSparron, 2008; Whitehouse et al., 2014). Moreover, several recent detailed pollen profiles serve to confirm that this pattern of farming activity characterises the Irish Neolithic at many sites (e.g. Selby et al., 2005; Taylor et al., 2017; Chique et al., 2017).

A strong upsurge in farming activity in the Chalcolithic and early Bronze Age (Chalcolithic begins at ca. 2500 BCE in Ireland; O'Brien, 2012) is another feature of the pollen 
profiles from north Mayo and Sligo as summarised in Fig. 10. An upsurge in farming at the about this time is well attested to by pollen profiles from various parts of Ireland and also Britain (McLaughlin et al., 2016).

\subsection{Mid-Holocene environmental change and human population dynamics - insights into forcing factors}

Valuable insights into local and regional environmental change during the periods referred to above are provided by a variety of sources including pollen profiles (e.g. water table reconstruction at GLU IV based on changes in local bog vegetation based largely on the pollen evidence) and the phenomenon of pine associated with bogs in north Mayo and also dendrochronological data with tight chronological control from further afield including central and northern Ireland, Scotland and northern Germany (Fig. 10). Though Irish bog pine generally shows a wide spread of dates (several millennia) and pollen profiles such as GRN I suggest more or less continuous presence of pine on the local bog surface, the concentration of dates centred on $3000 \mathrm{BCE}$ is striking. Significantly also, there are the fixed (cross-matched to the Irish fixed oak chronology) pine chronologies from northern Ireland and Scotland that are centred on this date (Pilcher et al., 1995; Moir et al., 2010). The floating dendrochronological pine record from raised-bog contexts in central Ireland is, however, younger (2500-2000 BCE; McNally and Doyle, 1984) and appears to be an outlier, at least as far as Ireland is concerned (but see Lageard et al., 1999).

Under present-day climatic conditions, pine does not colonise Irish bog surfaces in the absence of drainage or a disturbance such as fire (cf. O'Connell and Doyle, 1990) most likely because these habitats are too wet. The widespread pine colonisation of bog surfaces in the past, especially in instances where regional synchroneity can be demonstrated, was presumably triggered by climate shifts that involved less precipitation and/or high temperatures which, in turn, led to lower wetland water tables (cf. Achterberg et al., 2018; Eckstein et al., 2011). Such changes, rather than factors such as storms or fire, facilitated pine establishment and growth on bog surfaces (Eckstein et al., 2009). McGeever and Mitchell (2015), however, on a basis of a compilation of ${ }^{14} \mathrm{C}$ dates of Irish bog-pine timbers, question the validity of regarding climate change as the main factor leading to the high frequency of bog pine during the mid-Holocene in Ireland. We appreciate that several factors are undoubtedly involved, but, in our view, the regional synchroneity of the pine flush favours a climate-change explanation. We envisage that drier bog surfaces led to the widespread establishment and growth of pine on bog that, previously, had been too wet for tree growth.

Given that the intensity and timing of phases of farming activity as described here appear not to be positively correlated with fluctuations in climate (Fig. 10; especially the tree-ring (both pine and oak) records from Ireland and Ger- many), it is difficult to justify invoking climate change as the main factor determining levels of farming activity in the north Mayo region and indeed Ireland generally (cf. Krossa et al., 2017; Stevens and Fuller, 2015; Stolze et al., 2013; Turney et al., 2006, 2016; for a general discussion on determinism in archaeological contexts see Arponen et al., 2019a). Rather it would appear that farming and human population dynamics were more influenced by factors such as cultural developments and societal changes (cf. Plunkett et al., 2013; Bishop, 2015; Arponen et al., 2019b) and, in the case of north Mayo, blanket bog that was already locally extensive prior to the commencement of Neolithic farming but expanded considerably following the abandonment of or reduction in farming in the middle and later Neolithic.

\section{Conclusions}

Long pollen records from Céide Fields and Garrynagran, north Mayo, indicate substantial, and in the case of Céide Fields, major landnam, i.e. woodland clearance in the context of Neolithic farming. Landnam started from 3800 BCE, with the initial intensive phase lasting 400 years. We suggest that the stone-wall field system at Céide Fields was constructed during this time, which, as regards its early date and highly regular and extensive pattern, is unique in European Neolithic contexts (Fowler, 1983; Bakels, 2009). The early landnam phase was followed by a less intensive but yet substantial farming phase - well pronounced at Céide Fields of 300 years duration.

A distinct lull in farming activity characterised the middle and late Neolithic (3100-2350 BCE). Midway in this interval, there are signs of the resumption of farming in the pollen records. During this time the phenomenon of the pine flush is recorded, i.e. widespread establishment of pine on blanket bog. In this connection, it was possible to construct a floating pine chronology (P1M) at Garrynagran that spanned the interval 3135-2700 BCE. It is argued that the pine flush serves as a useful chronological tool, especially for the critical assessment of the age of basal peats in blanket-bog contexts at a regional level.

The long history of pine growing on peat surfaces in Co. Mayo is particularly well demonstrated by the evidence from Garrynagran where pollen and stomata and securely dated pine timbers (dendro- and ${ }^{14} \mathrm{C}$-dated) show that pine had a continuous presence on peat from 5700-2600 BCE (and almost certainly earlier (lower part of pollen core was not analysed) and possibly later). These and other records of pine of similar and older ages from blanket-bog contexts indicate relatively widespread presence of bog pine and, more significantly in the context of the possibilities for prehistoric farming, extensive blanket bog in the region prior to the beginning of Neolithic farming (cf. for a wider regional perspective on blanket-bog growth see Gallego-Sala et al., 2016; also O'Connell, 1990). 
Given that the pine flush centred on ca. 3100-2700 BCE is a regional phenomenon, it is argued that it signifies climate change involving decreased precipitation and/or higher temperatures that enabled pine to germinate freely and grow for many years on bog. At Garrynagran, of the dendrochronologically investigated pine timbers, 19 had $>100$ annual rings and eight had $>200$ annual rings, while only four had $<60$ annual rings (not used for matching). The three oak samples had $>150$ annual rings.

Expansion of blanket bog in areas that were previously farmed (pasture and also arable) at Céide Fields and Belderrig appears to be a phenomenon of the middle and late $\mathrm{Ne}$ olithic period rather than the Bronze Age. Given that major blanket-bog expansion coincides more or less with the pine flush, it is unlikely that the expansion was mainly the result of wetter conditions, i.e. climate-induced. The abandonment or neglect of previously farmed land and soil degradation, rather than a wetter and/or cooler climate, are more likely to have given rise to conditions favouring peat accumulation and bog expansion.

On the basis of the palaeoecological data available to us, we reassert the importance and intensity of farming (mainly pastoral but with an arable component) in the early Neolithic in north Mayo and elsewhere in the wider region. Furthermore, we suggest that the arguments presented by Whitefield (2017) for a reassessment of the age of the stone-wall field systems in north Mayo arise from a misunderstanding of the evidence and especially the palaeoecological records. We respectfully suggest that the arguments he proffers be rejected and, unless and until substantial new evidence becomes available, that the pre-bog field systems be regarded as pertaining to the Neolithic and indeed the earlier part of the Irish and British Neolithic, a view also shared by many archaeologists (e.g. Bradley, 2003; Cooney et al., 2011; Caulfield, 2018; Warren, 2018).

Data availability. Geographical details, results of ${ }^{14} \mathrm{C}$ dating, plots of pollen profiles Behy I-VI and other short profiles from Céide Fields and profile BDG1 from Belderrig, and photographs from Céide Fields, Belderrig and Garrynagran are provided in the Supplement. Data for pollen profiles analysed in the Palaeoenvironmental Research Unit (PRU), National University of Ireland Galway (NUIG) have been submitted to PANGAEA.

Supplement. The supplement related to this article is available online at: https://doi.org/10.5194/egqsj-69-1-2020-supplement.

Author contributions. Fieldwork at Céide Fields was carried out by $\mathrm{KM}$ and MO'C. KM was responsible for the pollen analytical and macrofossil investigations. Fieldwork at Garrynagran was carried out by EJ and MO'C. EJ carried out the pollen analytical and dendrochronological investigations in the context of a $\mathrm{PhD}$ project supervised by MO'C. This paper was drafted by MO'C and benefitted from inputs by KM and EJ.

Competing interests. The authors declare that they have no conflict of interest.

Acknowledgements. Seamas Caulfield and Gretta Byrne gave advice as to sampling sites and spent much time discussing the study area and its rich archaeology during visits to Céide Fields and Belderrig. Local landowners facilitated access to sampling sites. The Birrane family were unstinting in their hospitality extended during sampling at Garrynagran. Pádraic Cooke, Pat O'Rafferty and Noel Dunne helped with sampling in the field. Pádraic Breathnach and Tom Larkin (Physics) constructed the moving stage and wrote stage-PC interface software for tree-ring measurements. Dave Brown and Mike Baillie (QUB) gave advice and help to Eneda Jennings with dendrochronological investigations. Ingo Feeser made available his pollen handling program CountPol. Funding for the research was provided by The Heritage Council (Ireland) for Céide Fields, Forbairt/Eolas for the bog-pine investigations, and NUIG in the form of a Postgraduate Fellowship awarded to Eneda Jennings. We are grateful for the above support and the considerable help provided over several years by fellow researchers in the PRU.

Financial support. This research has been supported by the Heritage Council of Ireland (grant no. 1993), Forbairt/Eolas (Ireland; grant no. 1995) and an NUIG Postgraduate Fellowship (1992-1995).

The article processing charge was funded by the Quaternary scientific community, as represented by the host institution of EGQSJ, the German Quaternary Association (DEUQUA).

Review statement. This paper was edited by Ingmar Unkel and reviewed by Karl-Ernst Behre and one anonymous referee.

\section{References}

Aalen, F. H. A., Whelan, K., and Stout, M. (Eds.): Atlas of the Irish Rural Landscape, 2 edn., Cork University Press, Cork, 2011.

Achterberg, I. E. M., Eckstein, J., Birkholz, B., Bauerochse, A., and Leuschner, H. H.: Dendrochronologically dated pine stumps document phase-wise bog expansion at a northwest German site between ca. 6700 and ca. 3400 BC, Clim. Past, 14, 85-100, https://doi.org/10.5194/cp-14-85-2018, 2018.

Anon: Radiocarbon laboratories, Radiocarbon, 55, 2073-2096, 2013.

Arnoldussen, S. and van der Linden, M.: Palaeo-ecological and archaeological analysis of two Dutch Celtic fields (Zeijen-Noordse Veld and Wekerom-Lunteren): solving the puzzle of local Celtic field bank formation, Veget. Hist. Archaeobot., 26, 551-570, 2017.

Arponen, V. P. J., Dörfler, W., Feeser, I., Grimm, S., Groß, D., Hinz, M., Knitter, D., Müller-Scheeßel, N., Ott, K., and Ribeiro, A.: 
Environmental determinism and archaeology. Understanding and evaluating determinism in research design, Archaeol. Dialogues, 26, 1-9, 2019a.

Arponen, V. P. J., Dörfler, W., Feeser, I., Grimm, S., Groß, D., Hinz, M., Knitter, D., Müller-Scheeßel, N., Ott, K., and Ribeiro, A.: Two cultures in the times of interdisciplinary archaeology. A response to commentators, Archaeol. Dialogues, 26, 19-24, $2019 \mathrm{~b}$.

Baillie, M.: Do Irish bog oaks date the Shang dynasty?, Current Archaeol., 117, 310-313, 1994.

Baillie, M. G. L.: A view from outside: recognising the big picture, Quat. Proc., 7, 625-635, 1999.

Baillie, M. G. L. and Munro, M. A. R.: Irish tree rings, Santorini and volcanic dust veils, Nature, 322, 344-346, 1988.

Baillie, M. G. L. and Pilcher, J. R.: A simple crossdating program for tree-ring research, Tree-Ring Bull., 33, 7-14, 1973.

Bakels, C. C.: Western European Loess Belt, Agrarian History, 5300 BC-AD 1000, Springer, Dordrecht, 295 pp., https://doi.org/10.1007/978-1-4020-9840-6, 2009.

Behre, K.-E.: Frühe Ackersysteme, Düngemethoden und die Entstehung der Nordwestdeutschen Heiden, Archäol. Korrespondenzbl., 2000, 135-151, 2000.

Bell, J. and Watson, M.: A History of Irish Farming 1750-1950, Four Courts Press, Dublin, 2008.

Beug, H.-J.: Leitfaden der Pollenbestimmung für Mitteleuropa und angrenzende Gebiete, 2 edn., Friedrich Pfeil, München, 2015.

Birks, H. H.: Studies in the vegetational history of Scotland, IV., Pine stumps in the Scottish blanket peats, Phil. Trans. R. Soc. Lond. Ser. B, 270, 181-226, 1975.

Bishop, R. R.: Did Late Neolithic farming fail or flourish? A Scottish perspective on the evidence for Late $\mathrm{Ne}$ olithic arable cultivation in the British Isles, World Archaeol., https://doi.org/10.1080/00438243.2015.1072477, 2015.

Blaauw, M.: Methods and code for 'classical' age-modelling of radiocarbon sequences, Quat. Geochronol., 5, 512-518, 2010.

Bogaard, A., Fraser, R., Heaton, T. H. E., Wallace, M., Vaiglova, P., Charles, M., Jones, G., Evershed, R. P., Styring, A. K., Andersen, N. H., Arbogast, R. M., Bartosiewicz, L., Gardeisen, A., Kanstrup, M., Maier, U., Marinova, E., Ninov, L., Schäfer, M., and Stephan, E.: Crop manuring and intensive land management by Europe's first farmers, P. Natl. Acad. Sci. USA, 110, 1258912594, https://doi.org/10.1073/pnas.1305918110, 2013.

Boschiero, P., Latini, L., and Caulfield, S. (Eds.): The Céide Fields, Ireland, Fondazione Benetton, Treviso (Italy), 2018.

Bourke, D.: Pollen Analysis from Belderg, County Mayo, B. Sc. (Hons) Thesis (unpublished), Department of Botany, University College Dublin, Dublin, 1972.

Bradley, R.: Neolithic expectations, in: Neolithic Settlement in Ireland and Western Britain, edited by: Armit, I., Murphy, E., Nelis, E., and Simpson, D., Oxbow Books, Oxford, 218-222, 2003.

Bradshaw, R. and Browne, P.: Changing patterns in the post-glacial distribution of Pinus sylvestris in Ireland, J. Biogeog., 14, 237248, 1987.

Bridge, M. C., Haggart, B. A., and Lowe, J. J.: The history and palaeoclimatic significance of subfossil remains of Pinus sylvestris in blanket peats from Scotland, J. Ecol., 78, 77-99, 1990.

Bronk Ramsey, C.: Bayesian analysis of radiocarbon dates, Radiocarbon, 51, 337-360, 2009.
Byrne, G.: Glimpses into the past. Some natural and human imprints visible in the north Mayo landscape, in: The Céide Fields. Ireland, edited by: Boschiero, P., Latini, L., and Caulfield, S., Fondazione Benetton, Treviso (Italy), 75-91, 2018.

Byrne, G., Dunne, N., Caulfield, S., Warren, G., Walsh, P., McIlreavy, D., and Rathbone, S.: Archaeological Excavations in Association with the Construction of the Céide Visitor Centre (E494) Stratigraphic Report (Unpublished), University College Dublin (School of Archaeology), Dublin, available at: https://rms.ucd.ie/ufrs/!W_VA_PUB_REPORTS. EDIT?POPUP=TRUE\&object_id $=147460496$ (last access 14 June 2019), 2009.

Caseldine, C., Thompson, G., Langdon, C., and Hendon, D.: Evidence for an extreme climatic event on Achill Island, Co. Mayo, Ireland around 5200-5100 cal. yr BP, J. Quat. Sci., 20, 169-178, 2005.

Caulfield, S.: 1972:0024 - Beldergbeg, Mayo, Excavation Reports, available at: https://www.excavations.ie/report/1972/ Mayo/0000128/ (last access: 28 August 2018), 1972.

Caulfield, S.: 1973:0026 - Beldergbeg, Mayo, Excavation Reports, available at: https://www.excavations.ie/report/1973/ Mayo/0000161/ (last access: 28 August 2018), 1973.

Caulfield, S.: 1974:0031 - Beldergbeg, Mayo, Excavation Reports, available at: https://www.excavations.ie/report/1974/ Mayo/0000205/ (last access: 28 August 2018), 1974.

Caulfield, S.: 1975:28 - Beldergbeg, Mayo, available at: https: //www.excavations.ie/report/1975/Mayo/0000241/ (last access: 28 August 2018), 1975.

Caulfield, S.: 1975:25 - Beldergbeg, Mayo, available at: https: //www.excavations.ie/report/1976/Mayo/0000271/ (last access: 28 August 2018), 1976.

Caulfield, S.: Neolithic fields: the Irish evidence, in: Early Land Allotment in the British Isles. A Survey of Recent Work, edited by: Bowen, H. C. and Fowler, P. J., BAR British Ser. 48, Oxford, 137-143, 1978.

Caulfield, S.: Céide and Belderg Beg, A Guide to Two Prehistoric Farms in North Mayo, 1980.

Caulfield, S.: The Neolithic settlement of North Connaught, in: Landscape Archaeology in Ireland, edited by: Reeves-Smyth, T. and Hamond, F., BAR British Ser. 116, Oxford, 195-215, 1983.

Caulfield, S.: Céide Fields and Belderrig Guide, Morrigan Book Company, Killala, 1988.

Caulfield, S.: Céide Fields, Ballycastle, Co. Mayo, 1992.

Caulfield, S.: Céide Fields: Europe's oldest surviving dairy fields?, in: Secrets of the Irish Landscape, edited by: Jebb, M. and Crowley, C., Cork University Press, Cork, 95-100, 2013.

Caulfield, S.: Céide Fields and Belderrig Valley: four score years of research, in: Mayo History and Society: Interdisciplinary Essays on the History of An Irish County, edited by: Moran, G. and Ó Muraíle, N., Geography Publications, Dublin, 25-44, 2014.

Caulfield, S.: Céide Fields and Belderrig valley: eighty-four years of research, in: The Céide Fields. Ireland, edited by: Boschiero, P., Latini, L., and Caulfield, S., Fondazione Benetton, Treviso (Italy), 55-73, 2018.

Caulfield, S., O'Donnell, R. G., and Mitchell, P. I.: ${ }^{14} \mathrm{C}$ dating of a Neolithic field system at Céide Fields, County Mayo, Ireland, Radiocarbon, 40, 629-640, 1998.

Caulfield, S., Byrne, G., Dunne, N., and Warren, G. (Eds.): Neolithic and Bronze Age landscapes of North Mayo: Report 
2011 [INSTAR2 Report], UCD School of Archaeology, Dublin, available at: http://www.ucd.ie/archaeology/documentstore/ instarreports/northmayoproject/NBNM2009_SUMMARY_ REPORT.pdf (last access: 26 March 2012), 2011a.

Caulfield, S., Byrne, G., Dunne, N., and Warren, G. (Eds.): Excavations on Céide Hill, Behy and Glenulra, North Co. Mayo, 19631994. INSTAR2 Report, OPW, The Heritage Council and UCD School of Archaeology, Dublin, available at: http://www.ucd.ie/ archaeology/nbnm2011 (last access: 2 March 2017), 2011 b.

Caulfield, S., Byrne, G., and Warren, G.: The Céide Fields, in: North Mayo, IQUA Field Guide No. 31, edited by: Warren, G. M. and Davis, S., Irish Quaternary Association, Dublin, 90-99, 2013.

Chique, C., Molloy, K., and Potito, A. P.: Mid-Late Holocene vegetational history and land-use dynamics in County Monaghan, northeastern Ireland - the palynological record of Lough Muckno, J. North Atlantic, 32, 1-24, 2017.

Cooney, G., Bayliss, A., Healy, F., Whittle, A., Danaher, E., Cayney, L., Mallory, J., Smyth, J., Kador, T., and O'Sullivan, M.: Ireland, in: Gathering Time. Dating the Early Neolithic Enclosures of Southern Britain and Ireland, Vol. 2, edited by: Whittle, A., Healy, F., and Bayliss, A., Oxbow Books, Oxford, 562-669, 2011.

de Valéra, R.: Transeptal court cairns, J. R. Soc. Antiq. Ireland, 95, 5-37, 1965.

de Valéra, R. and Ó Nualláin, S.: Survey of the Megalithic Tombs of Ireland, Vol. II, County Mayo, Stationery Office, Dublin, 1964.

Dunne, N.: Pre-bog archaeology: the Glenamoy-Barnatra peninsula Co. Mayo, MA thesis (unpublished), UCD (Archaeology), Dublin, 1985.

Dwyer, R. B. and Mitchell, F. J. G.: Investigation of the environmental impact of remote volcanic activity on north Mayo, Ireland, during the mid-Holocene, Holocene, 7, 113-118, 1997.

Eckstein, J., Leuschner, H. H., Bauerochse, A., and Sass-Klaassen, U.: Subfossil bog-pine horizons document climate and ecosystem changes during the mid-Holocene, Dendrochron., 27, 129146, 2009.

Eckstein, J., Leuschner, H. H., and Bauerochse, A.: Mid-Holocene pine woodland phases and mire development - significance of dendroecological data from subfossil trees from northwest Germany, J. Veg. Sci., 22, 781-794, 2011.

Fowler, P. J.: The Farming of Prehistoric Britain, Cambridge University Press, Cambridge, 1983.

Fritts, H.: Tree Rings and Climate, Academic Press, London, 1976. Gaillard, M.-J., Sugita, S., Bunting, J., Dearing, J., and Bittmann, F.: Human impact on terrestrial ecosystems, pollen calibration and quantitative reconstruction of past land-cover, Veget. Hist. Archaeobot., 17, 415-418, 2008.

Gallego-Sala, A. V., Charman, D. J., Harrison, S. P., Li, G., and Prentice, I. C.: Climate-driven expansion of blanket bogs in Britain during the Holocene, Clim. Past, 12, 129-136, https://doi.org/10.5194/cp-12-129-2016, 2016.

Ghilardi, B. and O'Connell, M.: Fine-resolution pollen-analytical study of Holocene woodland dynamics and land use in north Sligo, Ireland, Boreas, 42, 623-649, 2013.

Graybill, D. A.: Revised computer programs for tree-ring research, Tree-Ring Bull., 39, 77-82, 1979.

Guttmann-Bond, E. B., Dungait, J. A. J., Brown, A., Bull, I. D., and Evershed, R. P.: Early Neolithic agriculture in County Mayo, Re- public of Ireland: geoarchaeology of the Céide Fields, Belderrig, and Rathlackan, J. North Atlantic, 30, 1-32, 2016.

Håkannson, S.: University of Lund radiocarbon dates VII, Radiocarbon, 16, 307-330, 1974.

Hawthorne, D. and Davis, S.: Patchico: pollen report, in: North Mayo, IQUA Field Guide No. 31, edited by: Warren, G. M. and Davis, S., Irish Quaternary Association, Dublin, 68-73, 2013.

Heiri, O., Lotter, A. F., and Lemcke, G.: Loss on ignition as a method for estimating organic and carbonate content in sediments: reproducibility and comparability of results, J. Paleolimnol., 25, 101-110, 2001.

Holmes, J. A., Leuenberger, M., Molloy, K., and O'Connell, M.: Younger Dryas and Holocene environmental change at the Atlantic fringe of Europe derived from lake-sediment stable-isotope records from western Ireland, Boreas, https://doi.org/10.1111/bor.12425, 2019.

Holmes, N., Warren, G., and Davis, S.: Palaeoenvironmental analyses from Cregganmore, in: North Mayo, IQUA Field Guide No. 31, edited by: Warren, G. M. and Davis, S., Irish Quaternary Association, Dublin, 82-89, 2013.

Jacobson, G. L. and Bradshaw, R. H. W.: The selection of sites for paleovegetational studies, Quat. Res., 16, 80-96, 1981.

Jennings, E.: Palaeoecological studies towards the reconstruction of the Holocene history of Pinus sylvestris L. in western Ireland, $\mathrm{Ph} . \mathrm{D}$. thesis (unpublished), National University of Ireland Galway, 1997.

Jessen, K.: Studies in the Late Quaternary deposits and flora-history of Ireland, Proc. R. Ir. Acad., 52B, 85-290, 1949.

Krossa, V. R., Moros, M., Leduc, G., Hinz, M., Blanz, T., and Schneider, R.: Regional climate change and the onset of farming in northern Germany and southern Scandinavia, Holocene, 27, 1589-1599, 2017.

Lageard, J. G. A., Chambers, F. M., and Thomas, P. A.: Climatic significance of the marginalization of Scots pine (Pinus sylvestris L.) c. $2500 \mathrm{BC}$ at White Moss, south Cheshire, UK, Holocene, 9, 321-331, 1999.

Leuschner, H. H., Bauerochse, A., and Metzler, A.: Environmental change, bog history and human impact around 2900 B.C. in NW Germany - preliminary results from a dendroecological study of a sub-fossil pine woodland at Campemoor, Dümmer Basin, Veget. Hist. Archaeobot., 16, 183-195, 2007.

McCormick, F.: Mammal bone studies from prehistoric Irish sites, in: Environmental Archaeology in Ireland, edited by: Murphy, E. M. and Whitehouse, N. J., Oxbow Books, Oxford, 77-101, 2007.

McGeever, A. H. and Mitchell, F. J. G.: Pine stumps in Irish peats: is their occurrence a valid proxy climate indicator? J. Quat. Sci., 30, 489-496, 2015.

McKeever, M. H.: Comparative palynological studies of two lake sites in western Ireland and north-western Spain, M.Sc. thesis, TCD, Dublin, 1984.

McKeever, M. and Davis, S.: Pollen analysis at Cregganmore lake, Co. Mayo, in: North Mayo, IQUA Field Guide No. 31, edited by: Warren, G. M. and Davis, S., Irish Quaternary Association, Dublin, 74-82, 2013.

McLaughlin, T. R., Whitehouse, N. J., Schulting, R. J., McClatchie, M., Barratt, P., and Bogaard, A.: The changing face of Neolithic and Bronze Age Ireland: a big data approach to the settlement and burial records, J. World Prehist., 29, 117-153, 2016. 
McNally, A. and Doyle, G. J.: A study of subfossil pine layers in a raised bog complex in the Irish midlands. I. Palaeowoodland extent and dynamics, Proc. R. Ir. Acad., 84B, 57-70, 1984.

McSparron, C.: 'Have you no homes to go to?', Archaeol. Ireland, 22, 18-21, 2008.

Mitchell, G. F.: Littleton Bog, Tipperary: an Irish agricultural record, J. R. Soc. Antiq. Ireland, 95, 121-132, 1965.

Moir, A. K., Leroy, S. A. G., and Helama, S.: Role of substrate on the dendroclimatic response of Scots pine from varying elevations in northern Scotland, Can. J. For. Res., 41, 822-838, 2011.

Molloy, K. and O'Connell, M.: Palaeoecological investigations towards the reconstruction of woodland and land-use history at Lough Sheeauns, Connemara, western Ireland, Rev. Palaeobot. Palynol., 67, 75-113, 1991.

Molloy, K. and O'Connell, M.: Palaeoecological investigations towards the reconstruction of environment and land-use changes during prehistory at Céide Fields, western Ireland, Prob. Küstenforsch., 23, 187-225, 1995.

Moore, J. J.: Zur Entstehung und Entwicklung der terrainbedeckenden Moore Westirlands, in: Gesellschaftsentwicklung (Syndynamik), edited by: Tüxen, R. and Sommer, W.-H., Cramer, Vaduz, 413-419, 1979.

Moore, P. D., Evans, A. T., and Chater, M.: Palynological and stratigraphic evidence for hydrological changes in mires associated with human activity, in: Anthropogenic Indicators in Pollen Diagrams, edited by: Behre, K.-E., Balkema, Rotterdam, 209-220, 1986.

Munro, M. A. R.: An improved algorithm for crossdating tree-ring series, Tree-Ring Bull., 44, 17-27, 1984.

Ní Ghráinne, E.: Palaeoecological studies towards the reconstruction of vegetation and land-use history of Inishbofin, western Ireland, Ph.D. thesis (unpublished), University College Galway [National University of Ireland Galway], 1993.

O'Brien, W.: Local Worlds. Early Settlement Landscapes and Upland Farming in South-west Ireland, Collins Press, Cork, 2009.

O'Brien, W.: The Chalcolithic in Ireland: a chronological and cultural framework, in: Is there a British Chalcolithic? People, Place and Polity in the Later Third Millennium, edited by: Allen, M. J., Gardiner, J., and Sheridan, A., The Prehistoric Society and Oxbow Books, Oxford, 211-225, 2012.

O'Connell, C. A. and Doyle, G. J.: Local vegetation history of a pine woodland on Clonfinane Bog, County Tipperary, in: Ecology and Conservation of Irish Peatlands, edited by: Doyle, G. J., Dublin, Royal Irish Academy, 23-40, 1990.

O'Connell, M.: Reconstruction of local landscape development in the post-Atlantic based on palaeoecological investigations at Carrownaglogh prehistoric field system, County Mayo, Ireland, Rev. Palaeobot. Palynol., 49, 117-176, 1986.

O'Connell, M.: Origins of Irish lowland blanket bog, in: Ecology and Conservation of Irish Peatlands, edited by: Doyle, G. J., Dublin, Royal Irish Academy, 49-71, 1990.

O'Connell, M. and McDonnell, K.: Holocene vegetation history of SW Connemara, Co. Galway with particular reference to Carna and Roundstone, in: The Quaternary of Western Ireland, INQUA 2019 Field Guide Pre:GL-2, edited by: Coxon, P., Irish Association for Quaternary Studies, Dublin, 83-102, 2019.

O'Connell, M. and Molloy, K.: Farming and woodland dynamics in Ireland during the Neolithic, Biol. Environ. (Proc. R. Ir. Acad. Ser. B), 101, 99-128, 2001.
O’Connell, M. and Ní Ghráinne, E.: Palaeoecology [of Inishbofin], in: Clare Island and Inishbofin, Field Guide No. 17, edited by: Coxon, P. and O'Connell, M., Irish Association for Quaternary Studies, Dublin, 60-103, 1994.

O'Connell, M., Mitchell, F. J. G., Readman, P. W., Doherty, T. J., and Murray, D. A.: Palaeoecological investigations towards the reconstruction of the post-glacial environment at Lough Doo, County Mayo, Ireland, J. Quat. Sci., 2, 149-164, 1987.

O'Connell, M., Ghilardi, B., and Morrison, L.: A 7000-year record of environmental change, including early farming impact, based on lake-sediment geochemistry and pollen data from County Sligo, western Ireland, Quat. Res. 81, 35-49, 2014.

O'Connell, M., Molloy, K., and Jennings, E.: Pollen analytical and bog-pine investigations relating to Céide Fields and Garrynagran, Co. Mayo, Ireland, PANGAEA, https://doi.org/10.1594/PANGAEA.911684, 2020.

O'Donnell, L.: Charcoal analysis from Neolithic and Bronze Age landscapes of north Mayo, in: Neolithic and Bronze Age Landscapes of North Mayo: Report 2011 [INSTAR2 Report], edited by: Caulfield, S., Byrne, G., Dunne, N., and Warren, G., UCD School of Archaeology, Dublin, 21-83, 2011.

Overland, A. and O'Connell, M.: Fine-spatial paleoecological investigations towards reconstructing late Holocene environmental change, landscape evolution and farming activity in Barrees, Beara Peninsula, southwestern Ireland, J. North Atlantic, 1, 37 73, 2008.

Pilcher, J. R., Baillie, M. G. L., Brown, D. M., McCormac, F. G., MacSweeney, P. B., and McLawrence, A. S.: Dendrochronology of subfossil pine in the north of Ireland, J. Ecol., 83, 665-671, 1995.

Plunkett, G., McDermott, C., Swindles, G. T., and Brown, D. M.: Environmental indifference? A critique of environmentally deterministic theories of peatland archaeological site construction in Ireland, Quat. Sci. Rev., 61, 17-31, 2013.

Praeger, R. L.: The Way that I Went, 3 edn. [1980 reprint], Figgis, Dublin, 1947.

Reimer, P. J., Bard, E., Bayliss, A., Beck, J. W., Blackwell, P. G., Bronk Ramsey, C., Buck, C. E., Cheng, H., Edwards, R. L., Friedrich, M., Grootes, P. M., Guilderson, T.P., Haflidason, H., Hajdas, I., Hatté, C., Heaton, T. J., Hoffmann, D. L., Hogg, A. G., Hughen, K. A., Kaiser, K. F., Kromer, B., Manning, S. W., Niu, M., Reimer, R. W., Richards, D. A., Scott, E. M., Southon, J. R., Staff, R. A., Turney, C. S. M., and van der Plicht, J.: IntCal13 and Marine13 radiocarbon age calibration curves 0-50,000 years cal BP, Radiocarbon, 55, 1869-1887, 2013.

Riede, F.: Environmental determinism and archaeology, Red flag, red herring, Archaeol. Dialogues, 26, 17-19, 2019.

Schulting, R. J., Murphy, E., Jones, C., and Warren, G.: New dates from the north and a proposed chronology for Irish court tombs, Proc. R. Ir. Acad., 112C, 1-60, 2012.

Selby, K. A., O'Brien, C. E., Brown, A. G., and Stuijts, I.: A multiproxy study of Holocene lake development, lake settlement and vegetation history in central Ireland, J. Quat. Sci., 20, 147-168, 2005.

Smith, A. G. and Goddard, I. C.: A 12500 year record of vegetational history at Sluggan Bog, Co. Antrim, N. Ireland (incorporating a pollen zone scheme for the nonspecialist), New Phytol., 118, 167-187, 1991. 
Smith, A. G. and Willis, E. H.: Radiocarbon dating of the Fallahogy Landnam phase, Ulster J. Archaeol., 24/25, 16-24, 1962.

Smith, A. G., Pearson, G. W., and Pilcher, J. R.: Belfast radiocarbon dates V, Radiocarbon, 15, 212-228, 1973.

Stevens, C. J. and Fuller, D. Q.: Alternative strategies to agriculture: the evidence for climatic shocks and cereal declines during the British Neolithic and Bronze Age (a reply to Bishop), World Archaeology, 47, 856-875, https://doi.org/10.1080/00438243.2015.1087330, 2015.

Stolze, S., Muscheler, R., Dörfler, W., and Nelle, O.: Solar influence on climate variability and human development during the Neolithic: evidence from a high-resolution multi-proxy record from Templevanny Lough, County Sligo, Ireland, Quat. Sci. Rev., 67, 138-159, 2013.

Taylor, K. J., Potito, A. P., Beilman, D. W., Ghilardi, B., and O'Connell, M.: Impact of early prehistoric farming on chironomid communities in northwest Ireland, J. Paleolimnol., 57, $227-$ 244, https://doi.org/10.1007/s10933-017-9942-6, 2017.

Turney, C. S. M., Baillie, M., Palmer, J., and Brown, D.: Holocene climatic change and past Irish societal response, J. Archaeol. Sci., 33, 34-38, 2006.

Turney, C. S. M., Jones, R. T., Thomas, Z. A., Palmer, J. G., and Brown, D.: Extreme wet conditions coincident with Bronze Age abandonment of upland areas in Britain, Anthropocene, 13, 6979, 2016.

Verrill, L. and Tipping, R.: A palynological and geoarchaeological investigation into Bronze Age farming at Belderg Beg, Co. Mayo, Ireland, J. Archaeol. Sci., 37, 1214-1225, 2010a.
Verrill, L. and Tipping, R.: Use and abandonment of a Neolithic field system at Belderrig, Co. Mayo, Ireland: evidence for economic marginality, Holocene, 20, 1011-1021, 2010 b.

Waddell, J.: The Prehistoric Archaeology of Ireland, 3 edn, Wordwell, Bray, 2010.

Warren, G.: The prehistoric archaeology of north Mayo, in: The Céide Fields, Ireland, edited by: Boschiero, P., Latini, L., and Caulfield, S., Fondazione Benetton, Treviso (Italy), 72-107, 2018.

Whitefield, A.: Neolithic 'Celtic' fields? A reinterpretation of the chronological evidence from Céide Fields in northwestern Ireland, European J. Archaeol., 20, 257-179, 2017.

Whitehouse, N. J., Schulting, R. J., McClatchie, M., Barratt, P., McLaughlin, T. R., Bogaard, A., Colledge, S., Marchant, R., Gaffrey, J., and Bunting, M. J.: Neolithic agriculture on the European western frontier: the boom and bust of early farming in Ireland, J. Archaeol. Sci., 51, 181-205, 2014.

Woodman, P. C.: The introduction of cattle into prehistoric Ireland: fresh perspectives, in: Cattle in Ancient and Modern Ireland: Farming Practices, Environment and Economy, edited by: O'Connell, M., Kelly, F., and McAdam, J. H., Cambridge Scholars Publishing, Newcastle upon Tyne, 12-26, 2016. 